\title{
Looking for Ephesian workshops: an integrated petrographic, geochemical, and chrono-typological approach to Late Hellenistic Ephesos lamps
}

\author{
Pamela Fragnoli ${ }^{1}$ [D $\cdot$ Marina Ugarković ${ }^{2}$ - Johannes H. Sterba ${ }^{3} \cdot$ Roman Sauer $^{4}$
}

Received: 26 April 2021 / Accepted: 22 July 2021 / Published online: 30 December 2021

(C) The Author(s) 2021

\begin{abstract}
In this pilot study, Late Hellenistic mold-made lamps from Ephesos are investigated by combining chrono-morphological and stylistic features with thin-section petrography and neutron activation analysis. Coeval wares of Ephesian production and clay samples collected around the site as well as published data from the Bonn database are considered local reference material. The results point to a network of local/regional workshops sharing facilities and/or a labor force dedicated to distinct tasks. The whole evidence is consistent with the very beginning of a nucleated workshop industry able to optimize the productivity of mold-made wares and fill the demand of an increased regional and supra-regional market. The typological and compositional variability of the latest phases could suggest a gradual transfer of potting activities towards areas providing better-suited clay sources.
\end{abstract}

Keywords Ephesos $\cdot$ Late Hellenistic mold-made lamps $\cdot$ workshops $\cdot$ craft organization $\cdot$ petrography $\cdot$ NAA

\section{Introduction}

Ephesos is one of the great Ionian Greek cities established along the coastal area of Asia Minor, near the mouth of the Menderes River (today Selçuk, south of Izmir, western Turkey). Despite the regional political upheavals, during the Hellenistic period and especially when it became the capital of the Roman Asia Minor province in $133 \mathrm{BCE}$, the city of

Pamela Fragnoli

pamela.fragnoli@oeaw.ac.at

Marina Ugarković

marina.ugarkovic@iarh.hr

Johannes H. Sterba

johannes.sterba@tuwien.ac.at

Roman Sauer

roman.rosa@aon.at

1 Research Group "Object Itineraries”, Department of Historical Archaeology of the Austrian Archaeological Institute, Austrian Academy of Science, Vienna, Austria

2 Institute of Archaeology, Jurjevska ulica 15, 10000 Zagreb, Croatia

3 Center for Labelling and Isotope Production, TRIGA Center Atominstitut, TU Wien, Vienna, Austria

4 Independent Researcher, Vienna, Austria
Ephesos ascended to one of the most important ancient metropolises and one of the most vital hubs in the eastern Mediterranean seascape (Ladstätter 2016).

An economic upturn visible in the $2^{\text {nd }} \mathrm{c}$. BCE embedded within its sociopolitical development was also marked by the strengthening of local crafts, including the notable ceramic production of finewares (Ladstätter 2016: 265). Ephesos lamps and mold-made relief bowls as well as plates and tablets of the so-called Ephesian Grey Ware (hereafter EGW) were, along with black- and red-gloss ware plates and bowls, the most important ceramic products attributable to the region of Ephesos in the period of the $2^{\text {nd }}$ and $1^{\text {st }} \mathrm{c}$. BCE (Ladstätter and Waldner in press). Even though particularities of the export of Late Hellenistic pottery from Ephesos are still under study, this was indeed the first time that ceramic wares manufactured in the workshops of Ephesos were used not only locally but also within regional and supra-regional circuits (Ladstätter 2007: 206; Ladstätter 2016: 265).

Ever since H. B. Walters introduced the term "Ephesus type" in his 1914 catalogue about Greek and Roman lamps kept at the British Museum (Walters 1914: 46-50), its slightly modified version, "Ephesos lamps," has been extensively used for specific types of Late Hellenistic mold-made lamps thought to have been created and produced in Ephesos and occasionally imitated elsewhere (on the terminology, see also Chrzanovski 2020). Though the term was simply motivated 
by the origin of the lamps stored in the British Museum (Walters 1914), its widely accepted use has also produced some ambiguities ever since. In this paper, the term "Ephesos lamps" is understood as defined by Anita Giuliani for different types of mold-made Late Hellenistic ceramic lamps produced in Ephesos and imitated elsewhere (Giuliani 2005b).

A great number of Ephesos lamps along with several molds for their manufacture that were discovered in different parts of this ancient city already testified to their local production (e.g., Walters 1914: 46-50; Miltner 1937: taf. XI, 7-21; Bailey 1975: 89-93; Gassner 1997: 192-194, 253, 254; Giuliani 2001 and 2005b; Mitsopoulos-Leon 2007; on mold finds: Miltner 1937: 200, nos. 1-2, Pl. 14; Bailey 1975: 90, 91, Q 181, Q 182, Pl.1, 34, Q 203, Pl. 1, 38; Mitsopoulos-Leon 1985: 247, Pl. 27, 28; Giuliani 2001; Mitsopoulos-Leon 2007: L 68. L 76. L 77). Although Ephesos seems not only to be one of the major production centers but also a birthplace of the different types and sub-types of Ephesos lamps, these latter have been also attested, though in significantly lower amounts, at various other Eastern Aegean and Asia Minor sites, such as Delos, Pergamon, Miletus, Priene, Knidos, Metropolis, Tralles, Aphrodisias, Kibyra, Assos, and Sardis (Bailey 1975; Chrzanovski 2020). It is assumed that the Pergamene workshops participated in this production and local copies are reported for Sardis, Metropolis, Tralles, Aphrodisias, Kibyra, and Assos as well. Numerous examples have also been found throughout the Mediterranean and Black Sea, with reported imitations of the latest and most famous type - known as the Howland 49 type - on several localities, such as Nea Paphos on Cyprus, Corinth, Athens, and Thessaloniki as well as the Pontic sites of Myrmekion, Pantikapaion, Chersonesos, and Olbia (e.g., Broneer 1930: 66-70; Howland 1958; Bruneau 1965: pl. 16-18; Bailey 1975: 91; Drougou 2012; Kajzer 2013; Zhuravlev and Zhuravleva 2014; Ugarković 2016: 12-14; Chrzanovski 2020; James 2020; Sheiko 2020). So far, local imitations have been mainly hypothesized on the basis of macroscopic criteria (e.g., typology and macro-fabrics), while archaeometric data and evidence of in situ primary productions (e.g., kilns, molds, or wasters) are almost totally lacking both in Asia Minor and beyond with the exception of Nea Paphos on Cyprus (Kajzer 2013, 2016, 2017).

Whether the dispersal of Ephesos lamps is the result of regular trade or should be regarded as evidence of secondary cargo and/or souvenirs, the Ephesos lamps are in any case among the most widely distributed ceramic products of Ephesian Late Hellenistic ceramic workshops and, as such, they can be considered an archaeological marker for the upsurge in mobility that took place during the advanced/late $2^{\text {nd }}$ and especially the $1^{\text {st }}$ c. BCE (Giuliani 2005b and 2008; Ladstätter 2007: 206). Through the modes of appropriation and imitation in various Mediterranean-wide communities and beyond (Chrzanovski 2020), Ephesos lamps can be also viewed in the light of choices maintained through multicultural interaction and cultural transfer. Such a phenomenon was not achieved with any other type of Hellenistic lamps, certainly not to such an extent.

The present paper employs a multi-proxy approach that combines morphological, stylistic, petrographic, and geochemical analyses. Previous petrographic and geochemical analyses conducted by Roman Sauer and Gerwulf Schneider suggested a local and/or regional production showing similarities with mold-made relief bowls and EGW (Sauer 1995a and 1995b; Zabehlicky-Scheffenegger et al. 1996; Ladstätter 2007; Hintermann 2016). Although pottery workshops of the Hellenistic period have still not been discovered in Ephesos, this argument is supported by the association of mold-made relief bowls and the molds for their manufacturing (c. 70 fragments that belonged to the main production of Ephesian mold-made relief bowls, i.e., the so-called ПАРworkshop), Ephesos lamps, EGW, and other Late Hellenistic fine tablewares discovered in the Magnesian Gate (Seiterle 1982; Rogl 2001; Giuliani and Rogl 2002; Rogl 2014). Even though these were found in a secondary deposition of the early $1^{\text {st }} \mathrm{c}$. CE, the existence of the potter's quarter in the vicinity has been assumed (Seiterle 1982: 149; Sokolicek 2009: 341; Waldner personal communication). The abovementioned archaeological evidence and archeometric analysis made on limited samples clearly supported the local production of Ephesos lamps in Ephesos; however, how these were really made was never a subject of any in-depth study. By enlarging the previous set of analyses with new samples and analytical methods and integrating the results with archaeological criteria, we aim at further defining how the local production was organized. In particular, we intend to clarify whether there were a few or many workshops producing Ephesos lamps in the region, what the distinctive features of these workshops were, and to what extent they were specialized and connected to the production of other coeval fine wares. Achieving these objectives is the necessary prerequisite to properly investigating the Mediterranean-wide dispersal of Ephesos lamps in terms of imports, imitations, and adaptations.

\section{Archaeological context and ceramic repertoire}

The Ephesian production of Late Hellenistic lamps is typically obtained through reducing firing atmospheres, which lends them the typical grey color of the fabric and the dark greyblack to grey, dully shining coating. Nevertheless, examples fired in an oxidizing atmosphere occur as well (Fig. 2d), though less commonly (Bussière and Lindros Wohl 2017: 30, 37). A distinctive micaceous fabric, with small quartz 
and calcareous inclusions, can be recognized with the naked eye. Furthermore, Ephesos lamps are characterized by specific morphological traits and an eye-catching relief decoration that combines a wide range of different motifs. Morphological and stylistic studies conducted by Giuliani have identified six main groups of Hellenistic mold-made lamps thought to have originated in the workshops of Ephesos, each with several specific (sub-)types produced and used from the middle of the $2^{\text {nd }} \mathrm{c}$. BCE until the first decades of the $1^{\text {st }} \mathrm{c}$. AD (Giuliani 2001, 2004, 2005a, b, 2011). The study of the motifs' appearance and the preserved signatures has indicated that Ephesos lamps were produced by various craftspeople in different workshops (Giuliani 2001). One of the oldest, largest, and possibly most long-lived workshop was that of Asklepiades, whose products were exported from the early onset of their production, as evidenced by more than 50 pieces bearing this signature that are attested in Ephesos and around the Mediterranean (Giuliani 2005 b: 140, 141 and 2008: 92, n. 112).

Despite numerous hints at the existence of workshops in Ephesos associated with the production of Late Hellenistic tableware and lamps, such workshops have not been discovered yet (Ladstätter 2007: 206; Rogl 2014: 116; Ladstätter 2016: 265). However, several studies could cast light on many aspects of this production and the related socio-cultural phenomena (Mitsopoulos-Leon 1985; Giuliani and Rogl 2002; Rogl 2014; Ladstätter and Waldner in press). Besides the Ephesos lamps, typical locally produced tableware included cups with relief decoration (mold-made relief bowls), blackand red-gloss ware, Ephesian Grey Ware (EGW), and thinwalled pottery. Notwithstanding the typo-chronological groundwork, Ephesian pottery studies have in the last decades taken a turn towards a more contextual and interdisciplinary approach. Moreover, several important contexts have recently emerged in Ephesos that have benefited the study of Ephesos lamps as well. Over the years the comparison between the mold-made relief bowls and lamps has been of particular interest, also due to noticeable similarities of the decorative motifs (Giuliani and Rogl 2002). The current evidence suggests that the production of mold-made relief bowls in Ephesos (the so-called Süd-Atelier) started in the first half of the $2^{\text {nd }} \mathrm{c}$. BCE and more probably in its second quarter, as none have been recovered from the fill of the western stoas (the so-called Störgraben), which is dated to 190 BCE (Rogl 2014: 132). Thus, the first mold-made relief bowls are slightly older than the first type of Ephesos lamps (group 1, see below) in the Lower Agora, dated to around the middle of the $2^{\text {nd }} \mathrm{c}$. BCE or shortly after (Giuliani 2008: 90, 91). The published assemblages from Terrace House 2 show that the latest and most famous type of Ephesos lamps, known also as Howland 49A (here group 6 , see below), appears at the end of the $2^{\text {nd }} /$ beginning of the $1^{\text {st }} \mathrm{c}$. BCE and is mostly widespread during the $1^{\text {st }}$ c. BCE, when such lamps are frequently found together with mold-made relief bowls and black- and red-gloss wares (e.g., WE 7, Waldner 2016: 337, 361). Their presence is further observed in the layers dated to the first decades of the $1^{\text {st }} \mathrm{c}$. BCE, namely Late Augustan to Tiberian times, again in association with mold-made relief bowls and black- and red-gloss wares, but now also with thin-walled pottery, Eastern Sigillata A (ESA), Eastern Sigillata B (ESB), EGW and white-ground lagynoi (e.g., WE 7, Raum 41ain Waldner 2016: 334; also Waldner and Ladstätter 2014, WE 6, complex H/3; H-BI/1; WE 1, A-BI/1 and A-BI/4 in Ladstätter 2010: 174, 175, 177; WE 2, B-H/4 in Ladstätter 2010: 531). The presence of moldmade relief bowls in the latter contexts is, however, considered residual, since mid- $1^{\text {st }} \mathrm{c}$. BCE (or the third quarter of the $1^{\text {st }} \mathrm{c}$. BCE?) is treated as the time around which the manufacture of mold-made relief bowls in Ephesos had come to an end (Rogl 2014: 135). The Howland 49 A type of Ephesos lamps remained the predominant lighting device until the Augustan times, and after its latest appearance in the Late Augustan to Tiberian contexts, it was replaced by local lamps in the Italian style and the locally-regionally produced Red-on-White lamps (see Waldner 2016:367, n. 113, p. 370, and the diagram $1 \mathrm{~b}$ on p. 371 for a comparison of the presence of lamp types in the Augustan and Late Augustan second half of $1^{\text {st }} \mathrm{c}$. CE contexts; WE 4, Fundkomplex BI/1, BIV/2 Ladstätter 2005: 236, 241; Ladstätter and Waldner in press).

\section{Geological setting}

Ephesos is located in the Küçük Menderes valley at the point of contact between the Cycladic Metamorphic Complex to the west and the Menderes Massif to the east, both primarily defined by the presence of high-pressure metamorphic rocks (Okay 2001; Koralay et al. 2011). Çakmakoğlu s geological map reported in Figure 1 provides us with an exhaustive illustration of the different units exposed around the ancient city: the southeastern and eastern surroundings are dominated by the formations of Şirince Metaflysh, while the outcrops to the southwest, west, and north mostly relate to Efes Nappe (Çakmakoğlu 2007). The latter is in turn comprised of the Late Palaeozoic to Early Triassic Meryemana formation at the bottom and the Mesozoic Ayricadag formation at the top. The Meryemana formation crops out to the southwest and is dominated by mica-schists, quartz-schists, phyllites, and marbles. At the upper levels of this formation metavolcanics and gneissose schist lenses often occur (Çakmakoğlu 2007). The Ayrıcadağ formation-which is broadly exposed to the north but shows dispersed lenses to the west and southwest as well-contains marbles and metacarbonates. The Şirince Metaflysh has instead a pelitic matrix composed of phyllites, garnet-schists, and micaquartz-schists (Çakmakoğlu 2007). On specific locations within this matrix, tectonic slices or blocks of basic and 


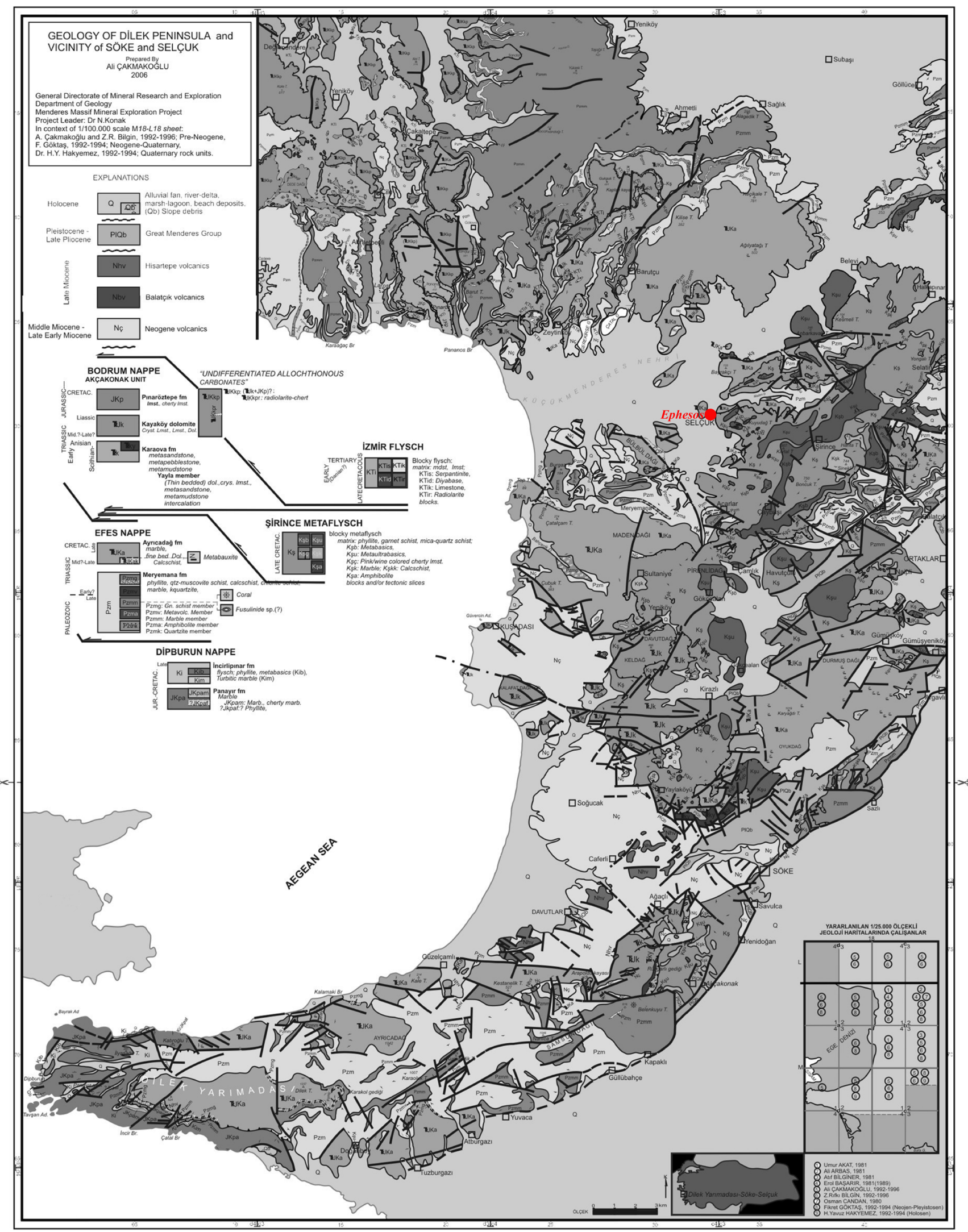

Fig. 1 Geological map of the region around Selçuk (Latitude DMS: $37^{\circ}$ 57' 3.04" N and longitude DMS: $27^{\circ} 22^{\prime} 11.83^{\prime \prime}$ E (after Google Maps).) (after Çakmakoğlu 2007). The red circle is a general indication of the location of ancient Ephesos 
ultrabasic rocks can occur, such as metadiabases, serpentinized dunites, and peridotites.

\section{Materials and methods}

For the purpose of this paper, 45 samples of Ephesos lamps (Table 1) were examined through thin-section petrography, and 20 of these samples were further analyzed through neutron activation analysis (NAA). The analyzed lamps were sampled by different scholars over the course of time: older samples are referred to as EPHL1-22 and EPH240-244, the most recent ones as EPHLAM1-20. Due to the lack of remaining material, NAA could not be applied to older samples, most of which are lacking a precise chrono-typological attribution as well. Given these limitations the present paper does not intend to offer an exhaustive scenario for Ephesos lamps but rather to (1) make use of unpublished samples and data collected in the last three decades of research in Ephesos; (2) provide one of the first systematic and integrated reference data for an area and period that played a significant role in ceramic production and trade; (3) perform an explorative pilot study to guide future samplings and analyses as well as to test the hypotheses so far supported on the basis of the archaeological evidence.

The analyzed materials mainly originate from different contexts of the Lower Agora (known also as the Tetragonos Agora) and Terrace House 2, while a few come from older excavations of the Basilica (Figs. 2 and 3). The samples incorporate several sub-types from the four main groups of Ephesos lamps (groups 1, 2, 5, and 6), based on the typology proposed by Giuliani. Lamps of group 1 have a small body with a sharp biconvex profile, high filling hole, flat or slightly curved shoulder, and mostly triangular nozzle and no handle (Fig. $2 \mathrm{a}$ and Fig. 3a-e). On the basis of the contextual analysis of Lower Agora assemblages, the limited series of sub-type 1 of group 1 (samples EPHL011, EPHLAM5, and EPHLAM12; Fig. 3b), with its specific motif variations, can be chronologically placed at the very beginning of the moldmade lamp production in Ephesos, around the middle of the $2^{\text {nd }}$ c. BCE or shortly after (Giuliani 2008: 90, 91). The subtype was already dispersed around the Aegean and it was possibly already connected with the Asklepiades workshop (Giuliani 2008: 92, n. 112). Sub-types 2 (samples EPHLAM1, EPHLAM14, and EPHLAM15; Fig. 3c, d) and 3 (samples EPHLAM2 and EPHLAM3; Fig. 3a, d) of the group 1 have a similar date; they morphologically differentiate themselves by a slightly higher body and a different treatment of the area around the filling hole, as well as in the motif repertoire.

A series of lamps described as group 2 (sample EPHLAM16, from the Asklepiades workshop; Fig. 3f) are chronologically similar to group 1 , but they present a somewhat different body outline, most notably a collar around the whole lamp. Such lamps were still in use in the early $1^{\text {st }} \mathrm{c}$. BCE, as evident from an example found in Dwelling Unit 2 of Terrace House 2 (Ladstätter 2010: 533, B-K 339).

Group 5 (Fig. $3 g-j$ ) is morphologically different from group 1 mainly due to a wider ring around the disk, while several types, with a variety of motifs, are identified by a different treatment of the area surrounding the filling hole (samples EPHLAM4, EPHLAM7, and EPHLAM13 belong to sub-type 5.2; sample EPHLAM8 belongs to sub-type 5.3). These have been dated to the third quarter of the $2^{\text {nd }} \mathrm{c}$. BCE and some to the later $2^{\text {nd }}$ and (early?) $1^{\text {st }} \mathrm{c}$. BCE, the latter also being corroborated by an example of an ATP monogram among our samples, contextually dated to the $1^{\text {st }} \mathrm{c}$. BCE (EPHLAM7); whereas sub-type 5.3 has been seen as a direct prototype for the last and most known group of Ephesos lamps (group 6).

The samples of group 6 (Fig. $3 \mathrm{k}-\mathrm{n}$ ) typically refer to the youngest and most widespread type of Ephesos lamps, known also as Howland 49A type, which is characterized by a biconical body, flaring collar around the disk, ribbon handle, and obligatory oil-holes (samples EPH15, EPH19, EPH21, EPH241-243, EPHLAM9-11, EPHLAM18, and EPHLAM19). As noted above, their manufacture commenced in the late $2^{\text {nd }} / 1^{\text {st }} B C$, and lasted until the Late Augustan (early Tiberian?) times, and during this time they were the most common lamp type (Giuliani 2005: 140, 141, abb. 2, 2,3, and 2008: 92). Such lamps were undoubtedly produced in a number of workshops and were the first type to be clearly imitated outside Ephesos as well. Even though precise typological attributions were in many cases not possible, especially for old samples, significant information could be drawn from the decorative motifs, signatures, and even firing procedures. For instance, EPHLAM6 is decorated with a lanceolateshaped leaf, which is generally associated with earliest types such as those represented by EPHLAM2. By contrast, EPHL022 decorated with Eros and grapes might be contemporary to lamps of group 6 , though belonging to a distinct type. Typical of later types as well is either the association of rounded nozzles and oxidizing firing atmospheres (e.g., EPHL015 and EPHL019) or a row of double spirals (e.g., EPHL015), which respectively characterize the unattributed samples EPHLAM20 and EPH240. More generally, oxidizing firings like in EPHL013 and EPHL020 are known to occur mostly in later phases as a transition towards the Sigillata production. Finally, the small preserved base of EPHLAM17 did not enable any chrono-typological attributions but provided the signature of the Asklepiades workshop.

As an attempt to compensate for the limitations of the dataset, we also included data from other local fine wares as reference material. As already stated above, the two methods 


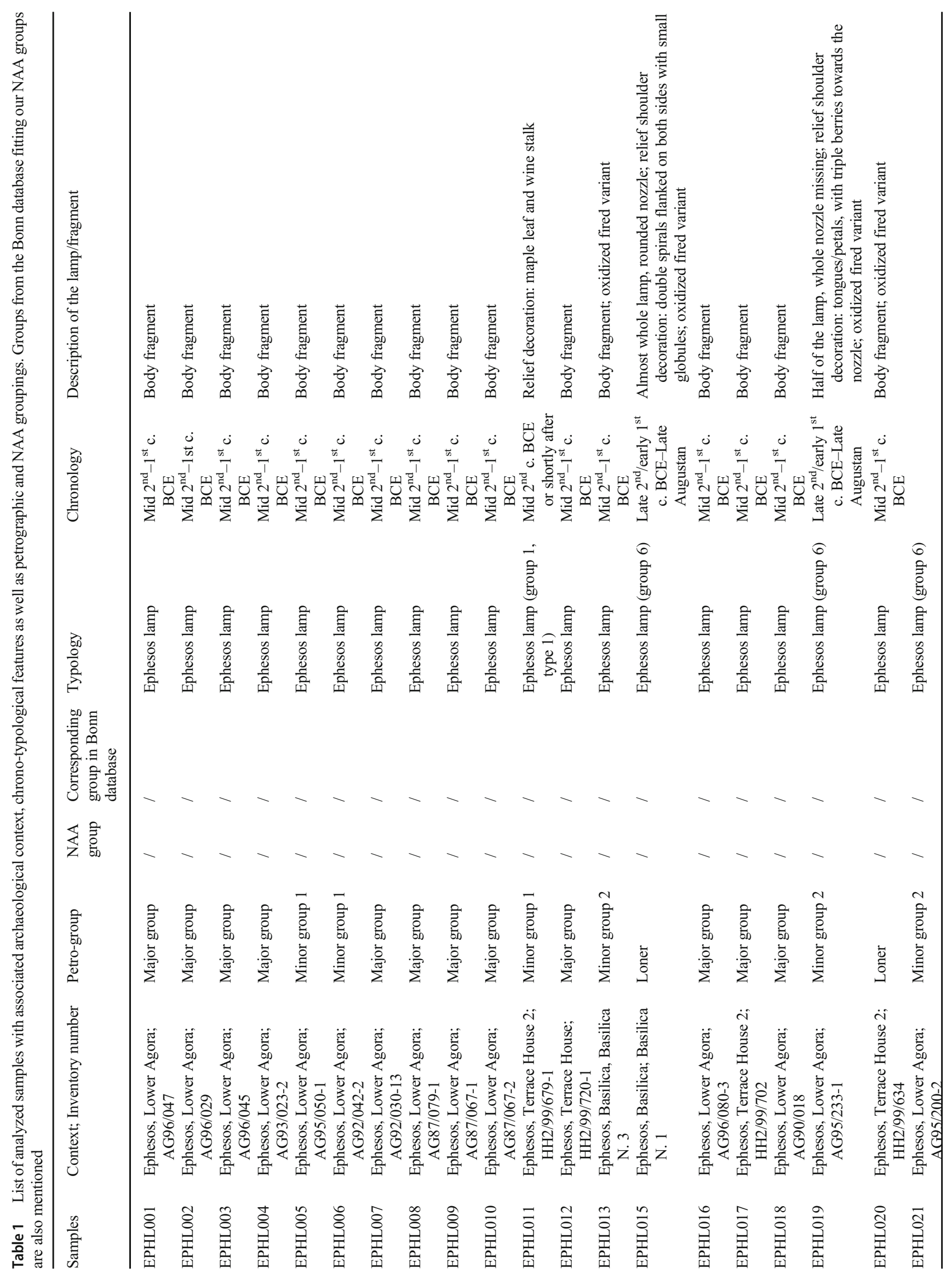




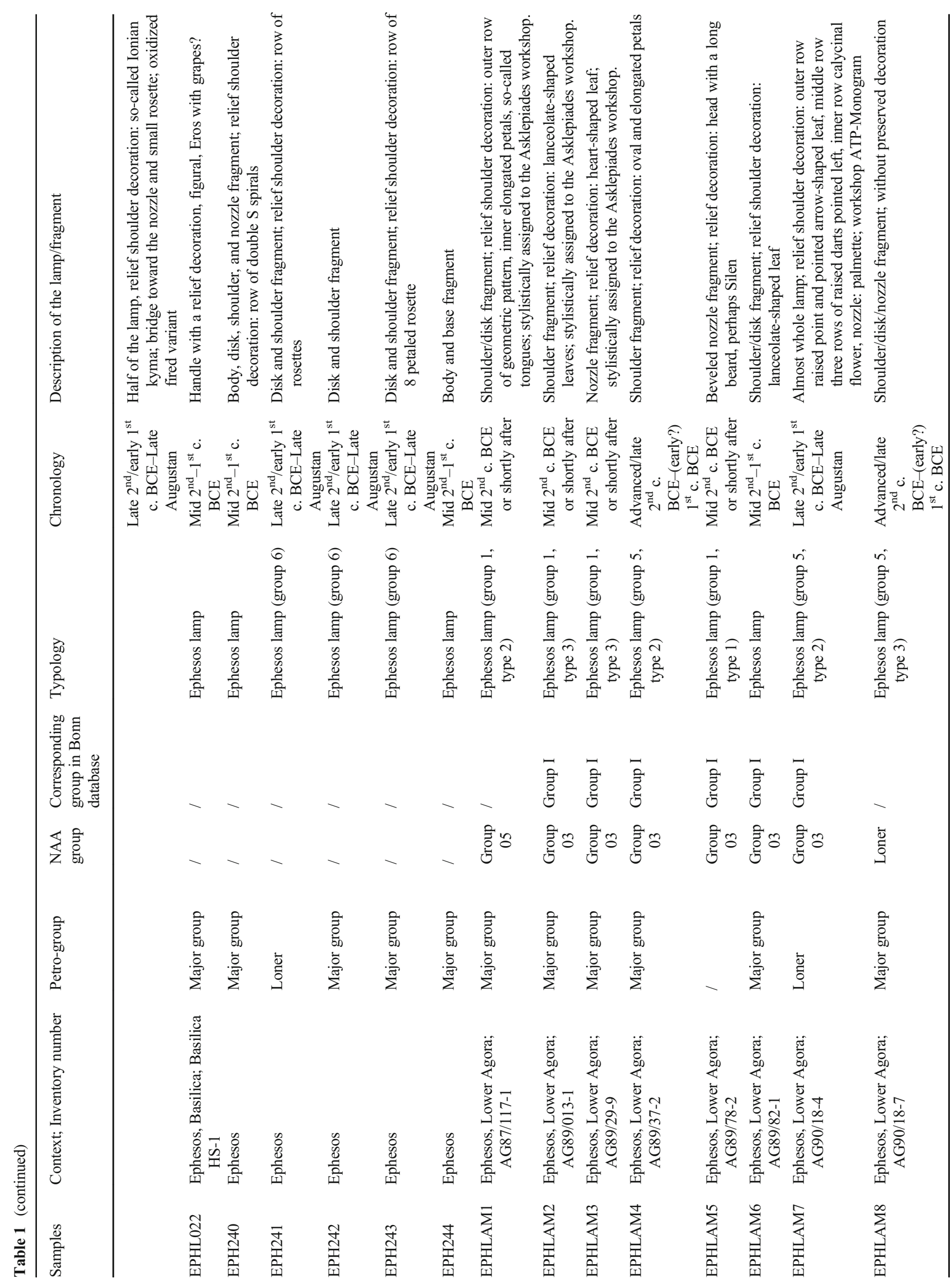




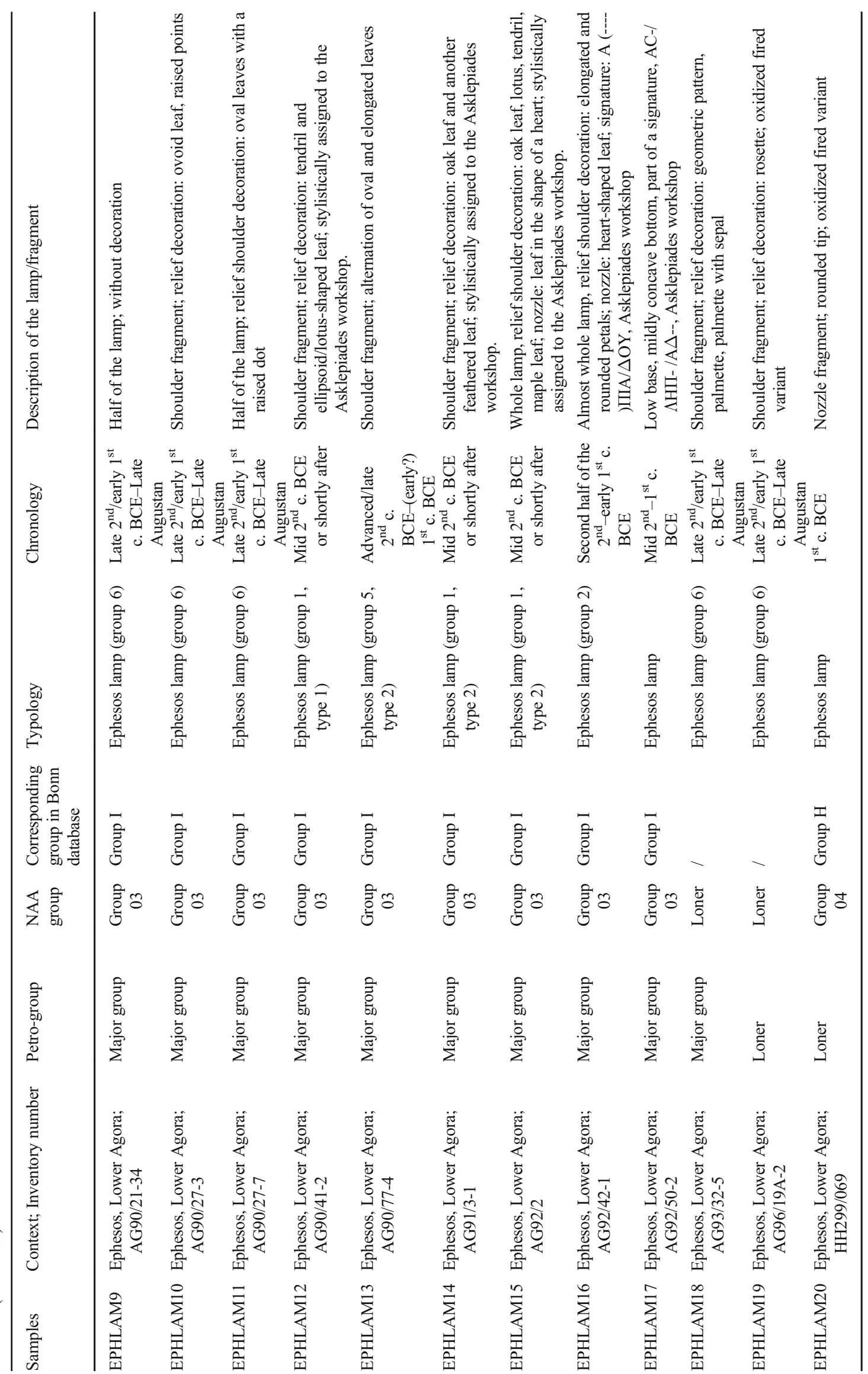



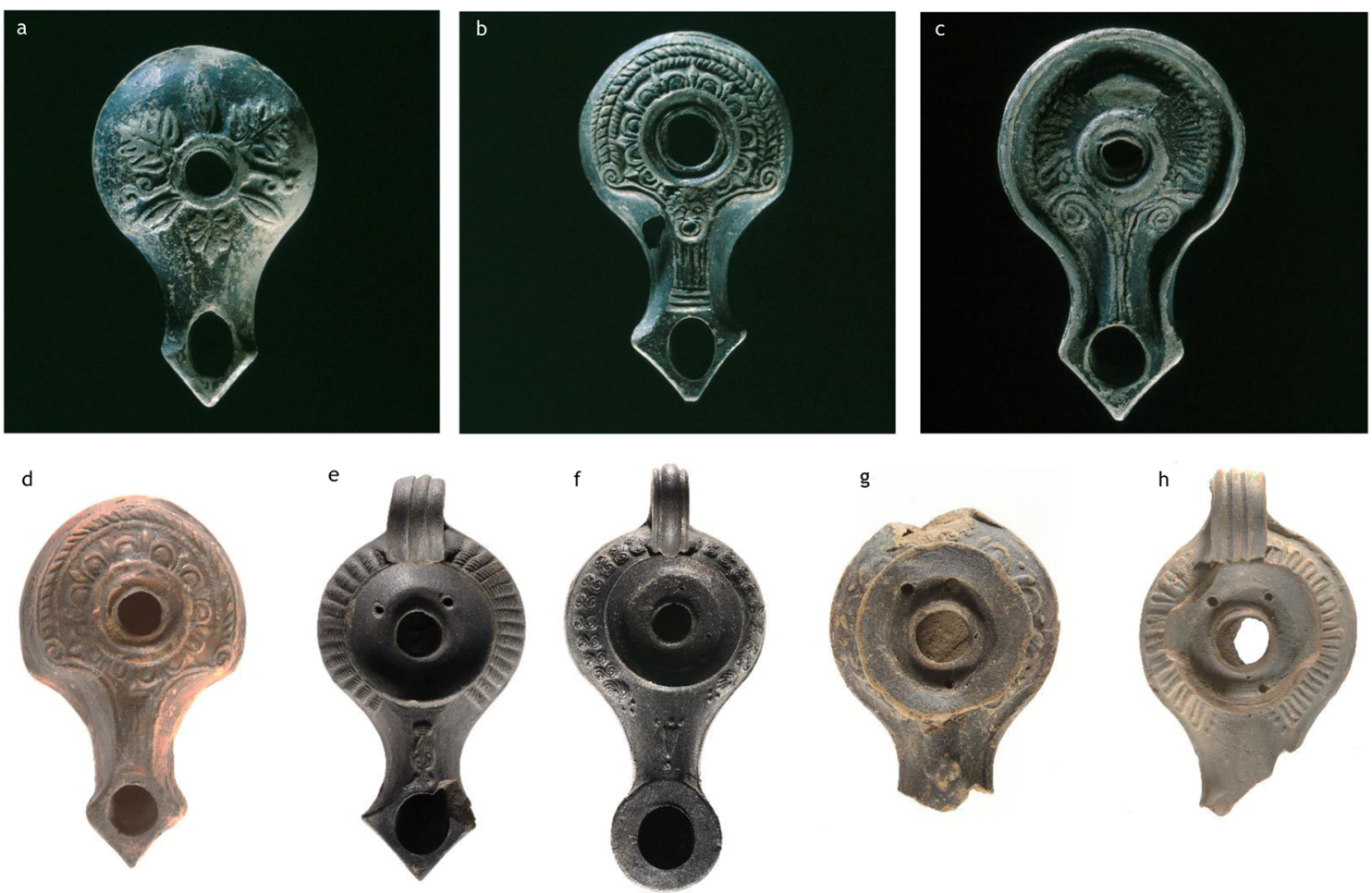

Fig. 2 Pictures of types and variants of Ephesos lamps represented in this study: (a) group 1, sub-type 1 (shoulder decoration: maple leaf, wine stalk, and lotus); (b) group 1, sub-type 2 (shoulder decoration: ovules with three arches with rhomboids in between, triple row of cable pattern, four raised nozzle ridges from which the outer turn into a volute on each side of the shoulder with a mask towards the nozzle; (c) group 2 (shoulder decoration: raised oval leaves; three raised nozzle ridges from which the outer turn into a volute on each side of shoulder;

applied here do not fully overlap; this reflects the compromises in our efforts to integrate old and new data and make the most efficient use of the remaining materials to be analyzed.

\section{Thin-section petrography}

The inclusions, clay matrix, and porosity of 45 thin sections were examined under a standard polarizing microscope, i.e., LEICA DM 2700P. The aim was to group the ceramic thin sections according to common strategies in the procurement and manipulation of raw materials. The resulting petro-groups were described and documented through photomicrographs at different magnifications. Comparative charts were used to quantify the main components (Rice 1987: 348).

The obtained results were interpreted within a wider reference database including 192 thin sections of other more and less coeval local wares - i.e., EGW, mold-made relief bowls and ESB - and clay samples collected around Ephesos and in the Meander Valley. Through an extensive survey, more than 200 clay deposits - some of which provided evidence of ancient or modern exploitation - were sampled in 1991 by R. Sauer, R. Jindra, M. J. Haiden and U. Outschar, in 2002 by S. triple berries between the volute and leaves); (d) group 6 (shoulder decoration: vertical cable pattern); (e) group 6 (shoulder decoration: double S spiral); (f) group 1, sub-type 2 (shoulder decoration: so-called Ionian kyma, two rows of cable pattern, four raised nozzle ridges from which the outer turn into a volute on each side of shoulder); (g) group 6; (h) group 6 (shoulder decoration: tongues/pointed-oval leaves, triple berries towards the nozzle). Photos by: Niki Gail, OeAW-OeAI

Ladstätter, R. Sauer, and B. Pichler, as well as in 2014 by L. Peloschek (Peloschek 2015). Samples collected in the close surroundings of the ancient city include Neogene alluvial or continental freshwater deposits, red lateritic weathering loams developed on carbonates or crystalline schists, soils developed on crystalline rocks available close to the Magnesian Gate in the Agora, as well as silty clays near the Artemision and harbor basin. The samples taken in the Küçük Meander Valley consist of Quaternary alluvial deposits. The petrographic, mineralogical and chemical analyses applied to these samples are the object of a separate publication in preparation and thus will not be discussed here in detail.

\section{Neutron activation analysis}

Twenty samples of Ephesos lamps were subjected to the standard analytical protocols for NAA of ceramics at the Atominstitut in Vienna (Sterba 2018). Sample size was approximately $100 \mathrm{mg}$ per sample; irradiation time was 35 hours at a neutron flux density of $1 \cdot 10^{13} \mathrm{~cm}^{-2} \mathrm{~s}^{-1}$. For quantification, internationally certified reference materials (CANMET reference soil SO1, NIST SRM 1633b Coal Fly Ash, Light Sandy Soil BCR No. 142, NIST SRM 2702 Inorganics in Marine 


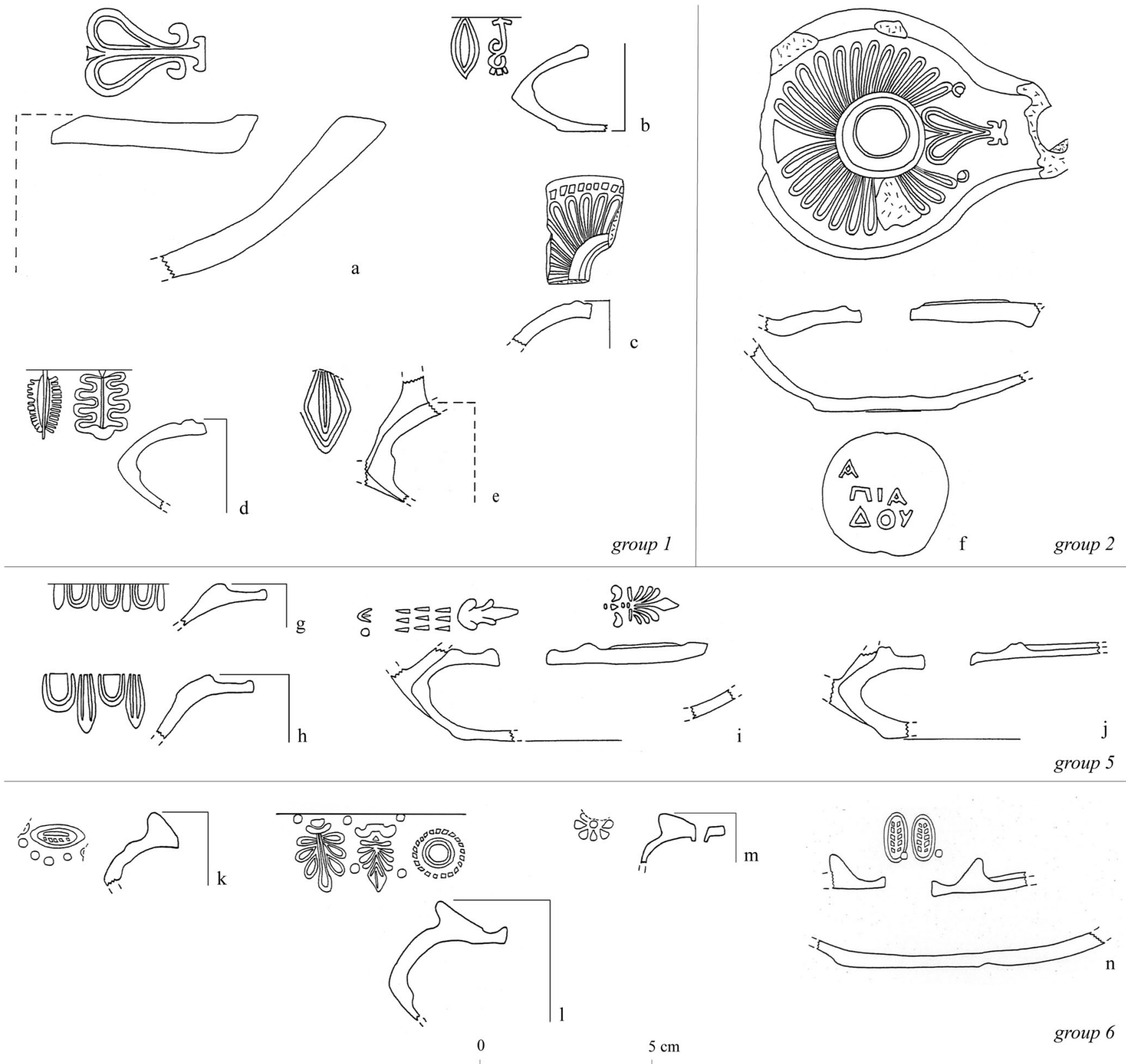

Fig. 3 Drawings of selected lamps analyzed in this paper: (a) EPHLAM3 (group 1, sub-type 3); (b) EPHLAM12 (group 1, sub-type 1); (c) EPHLAM1 (group 1, sub-type 2); (d) EPHLAM14 (group 1, sub-type 2); (e) EPHLAM2 (group 1, sub-type 3); (f) EPHLAM16 (group 2); (g)

Sediment, and MC Rhyolite GBW 07113) as well as the Bonn reference material (Mommsen and Sjöberg 2007) were irradiated and measured together with the samples. With data from two measurements of $1,800 \mathrm{~s}$ and $10,000 \mathrm{~s}$ after decay times of 4 days and 4 weeks, respectively, the concentrations of the elements sodium $(\mathrm{Na})$, potassium $(\mathrm{K})$, scandium $(\mathrm{Sc})$, chromium $(\mathrm{Cr})$, iron $(\mathrm{Fe})$, cobalt $(\mathrm{Co})$, nickel $(\mathrm{Ni})$, zinc $(\mathrm{Zn})$, arsenic $(\mathrm{As})$, rubidium $(\mathrm{Rb})$, strontium $(\mathrm{Sr})$, zirconium $(\mathrm{Zr})$, antimony $(\mathrm{Sb})$, caesium $(\mathrm{Cs})$, barium $(\mathrm{Ba})$, lanthanum $(\mathrm{La})$, cerium $(\mathrm{Ce})$, neodymium $(\mathrm{Nd})$, samarium $(\mathrm{Sm})$, europium $(\mathrm{Eu})$,
EPHLAM4 (group 5, sub-type 2); (h) EPHLAM13 (group 5, sub-type 2); (i) EPHLAM7 (group 5, sub-type 2); (j) EPHLAM8 (group 5, sub-type 3); (k) EPHLAM11 (group 6); (l) EPHLAM18 (group 6); (m) EPHLAM19 (group 6); (n) EPHLAM10 (group 6)

terbium $(\mathrm{Tb})$, ytterbium $(\mathrm{Yb})$, lutetium $(\mathrm{Lu})$, hafnium $(\mathrm{Hf})$, tantalum $(\mathrm{Ta})$, tungsten $(\mathrm{W})$, thorium $(\mathrm{Th})$, and uranium $(\mathrm{U})$ were calculated.

Statistical analysis of the raw data was done by applying the best relative-fit factor calculations (i.e., dilution correction) as established in Bonn (Beier and Mommsen 1994), grouping the samples according to their modified Mahalanobis distance. In this process, a distance measure - which factors in the individual measurement errors - is calculated for each pair of samples. This distance is then minimized under consideration 
of a possible dilution of the samples. This overcomes the potential statistical spread that results from the different content of water, silicon, or organic matter. Following this primary calculation, the distances are then used in an iterative process to find groups of samples.

The results were compared with $70 \mathrm{EGW}$ and ESB previously analyzed in Vienna as well as published data from the Bonn database (Kerschner et al. 2002; Akurgal et al. 2002; Kerschner 2007). From this latter database, two reference groups interpreted as local and named Groups $\mathrm{H}$ and I have been used for comparison. Although these groups mainly relate to the Ephesian ceramic workshop tradition during the $7^{\text {th }}$ and $6^{\text {th }} \mathrm{c}$. BCE, they also include vessels from the original Hellenistic fills and molds of Hellenistic mold-made relief bowls found in the Magnesian gate.

\section{Results}

\section{Thin-Section Petrography}

The components mostly recurring in ceramic thin sections are quartz (generally monocrystalline and more rarely polycrystalline), muscovite, biotite, carbonate grains, $\mathrm{K}$-feldspars, plagioclase, iron oxides, and quartz-schists (with both muscovite and biotite). The samples differ in optical activity, color, the calcareous or micaceous nature of the matrix, the grain-size distribution of inclusions, and the presence of slipping layers covering the vessel surfaces. Based on these differences the thin sections were divided into one major and two minor groups plus a small number of loners. The former includes 33 samples, while the two minor groups are each represented by three samples (Tables 1 and 2).

The major group (Fig. 4A-H) shows a calcareous, brown (both in PPL and XP), and isotropic clay matrix. Variation in color and grain-size distribution often occurs across the matrix, which indicates both different degrees of carbonate recrystallization after a high firing temperature and mixing procedures not sufficiently homogenized by working. Inclusions exhibit a unimodal distribution between 0.15 and $0.4 \mathrm{~mm}$ and a percentage abundance of $10 \%$. The altered absorption colors of biotite inclusions in plane polarized light (Fig. 4C) are due to firing temperatures reaching at least $900^{\circ} \mathrm{C}$. The high firing temperatures also determined the dissociation of carbonates, which significantly increased the porosity of the clay matrix characterized by typical yellowish pores. ${ }^{1}$ Besides the most recurrent minerals and rocks mentioned above, some samples also contain a few sandstones with carbonate cements (Fig. 4B) and very few marbles. Though only in traces, altered

\footnotetext{
${ }^{1}$ The observations of firing and finishing procedures made under the polarizing microscope evidenced initial differences that need to be further investigated through additional methods (e.g., SEM).
}

volcanic rocks with alkali feldspars (Fig. 4D), chert, and epidote appear in isolated samples.

The surfaces of most of the samples were covered with a clay slip layer, which strongly varies in terms of color, compactness, thickness, grain-size distribution, and optical activity (Fig. 4E-H). Some slip layers are optically more active than the underlying ceramic body, which is presumably due to the use of distinct raw materials, namely with different sintering degrees. Cases of double-layered slips have been observed as well (e.g., EPHL017, Fig. 4G). Similar evidence is known for the black-glaze Campana A vessels from south Tyrrhenian, Italy, and has been interpreted as a means to obtain the typical metallic shine of this ware (De Bonis et al. 2017). Differences in the slip layers inevitably affect the functional and aesthetic features of the end products. Non-vitrified slips have an increased permeability, shine, and scratch resistance. A higher permeability is in turn responsible for an increased seepage of oil into the porous clay body. However, in all cases, the slip adheres well and has similar dilatometric behaviors as the ceramic body.

The samples of the first minor group (Fig. 5A, B; Table 2) differ by the more frequent occurrence of muscovite, the higher incidence of inclusions (15-20\%), as well as the lack of sandstones. EPHL011 differs by the presence in trace of mica-schists, epidotes, and marble altered by firing. Trace of altered volcanic rocks is only present in EPHL006. As in the major group, carbonate-rich components were dissociated through the firing process.

The second minor petro-group (Fig. 5C, D; Table 2) is distinguished by the features of the clay matrix, which is micaceous, non-calcareous, slightly to moderately active, and brown-reddish colored (both in PPL and XP). The lamps of this group were thus produced with different clay raw materials and fired at lower temperatures and under different conditions, i.e., oxidizing atmospheres. The variety of inclusions also differs, comprising gneisses ${ }^{2}$ and amphiboles besides the minerals and rocks mentioned above (muscovite, quartz, quartz-schists, feldspars, plagioclase, and biotite). In contrast to the major and first minor groups, biotite minerals were not altered by the firing process and carbonate grains are lacking. Moreover, inclusions display angular shapes, cloudy spatial arrangements, and a bimodal grain-size distribution, which might indicate a tempering action by potters. The surface treatments also differ from the other groups since slipping layers occur only very rarely.

Six samples (i.e., $13.3 \%$ of the total assemblage) could not be assigned to the above-mentioned petro-groups and are to be

\footnotetext{
${ }^{2}$ Though the fabrics are relatively fine, gneisses could be distinguished from quartz-schists based on the lack of a distinct schistosity, the more coarsegrained texture, and the lower amount of platy micaceous minerals.
} 
considered as loners (Fig. 5E-H, Table 3). These latter differ in the optical activity, nature, and color of the clay matrix as well as in the grain-size distribution rather than in the type of inclusions. Clay pastes with the most pronounced optical activity, micaceous nature, and yellow-orange-reddish colors (both in PPL and XP) as well as finest texture have been observed among the loners. The sample EPH241 (Fig. 5G, H) shows peculiar firing and finishing procedures, as suggested by the sandwich structure with dark core and reddish margins, the smaller grain size, and stronger orientation of inclusions towards the surfaces, as well as the slip layer with bloated pores. Color and structure variation from the core to the margins indicate an uneven distribution of heat within the ceramic body, which mostly occurs in cases of fast heating rates and short soaking times (Buxeda I Garrigós et al., 2003). According to the experimental work by Thér (2014), these are peculiar to a one-space firing structure where vessels are put in contact with the fuel, such as in a pit fire or bonfire. Furthermore, the finer layer under the surfaces suggests a strong burnishing action before the application of the clay slip. Some of the abovementioned characteristics could be the result of a firing accident; however, their association with peculiar finishing procedures and paste recipes reveals a certain degree of intentionality, even though attested only in one sample.

Ephesos lamps show affinities with other coeval wares (Fig. 6A, D) in terms of raw materials and paste recipes. The vast majority-represented by the major petro-group and the first minor petro-group (36 out of 45 samples representing $80 \%$ of the analyzed assemblage) - share the same recipes with mold-made relief bowls (Fig. 6A, B). The few oxidizing fired variants - such as those classified into the second minor petro-group $(=6.6 \%)$-correlate instead with EGW (Fig. 6C). Among loners, the finest oxidizing fired exemplars (e.g., EPHL015) are similar to some ESB (Fig. 6D).

The minero-petrographic associations of all thin sections (Tables 3 and 4) suggest the exploitation of local Neogene and Quaternary deposits, which formed from the weathering and/or transport of pelitic and carbonate metamorphic rocks. In particular, the weathering products of the Şirinçe Metaflysch and Meryemana formations located immediately east and south of the site- Kș and Pzm on the geological map in Fig. 1-and dominated by muscovitebiotite-quartz-schists were presumably exploited. The thin sections of clays collected around Ephesos and within the Küçük Menderes Valley further corroborate the local origin of raw materials (Fig. 6E-H). Besides frequent inclusions of quartz, feldspars, micas, carbonates, gneisses, and schists, local-fired clay occasionally include sandstones, volcanics, marbles, chert, hornblendes, and epidotes. However, based on the petrographic affinity of a very few lamps (e.g., EPH0L15) with ESB exemplars, a sporadic more distant sourcing beyond the Küçük Menderes Valley is not to be 
Fig. 4 Thin-section

microphotographs under XP (A, $\mathrm{B}$, and $\mathrm{E})$ and PPL (C, D, F, G, and $\mathrm{H}$ ) of Ephesos lamps representative of the major group: (A) EPHLAM2; (B) EPHLAM4; (C) EPHLAM9; (D) EPHL003;

(E) EPHLAM14; (F) EPHL008;

(G) EPHL017; (H) EPHLAM2
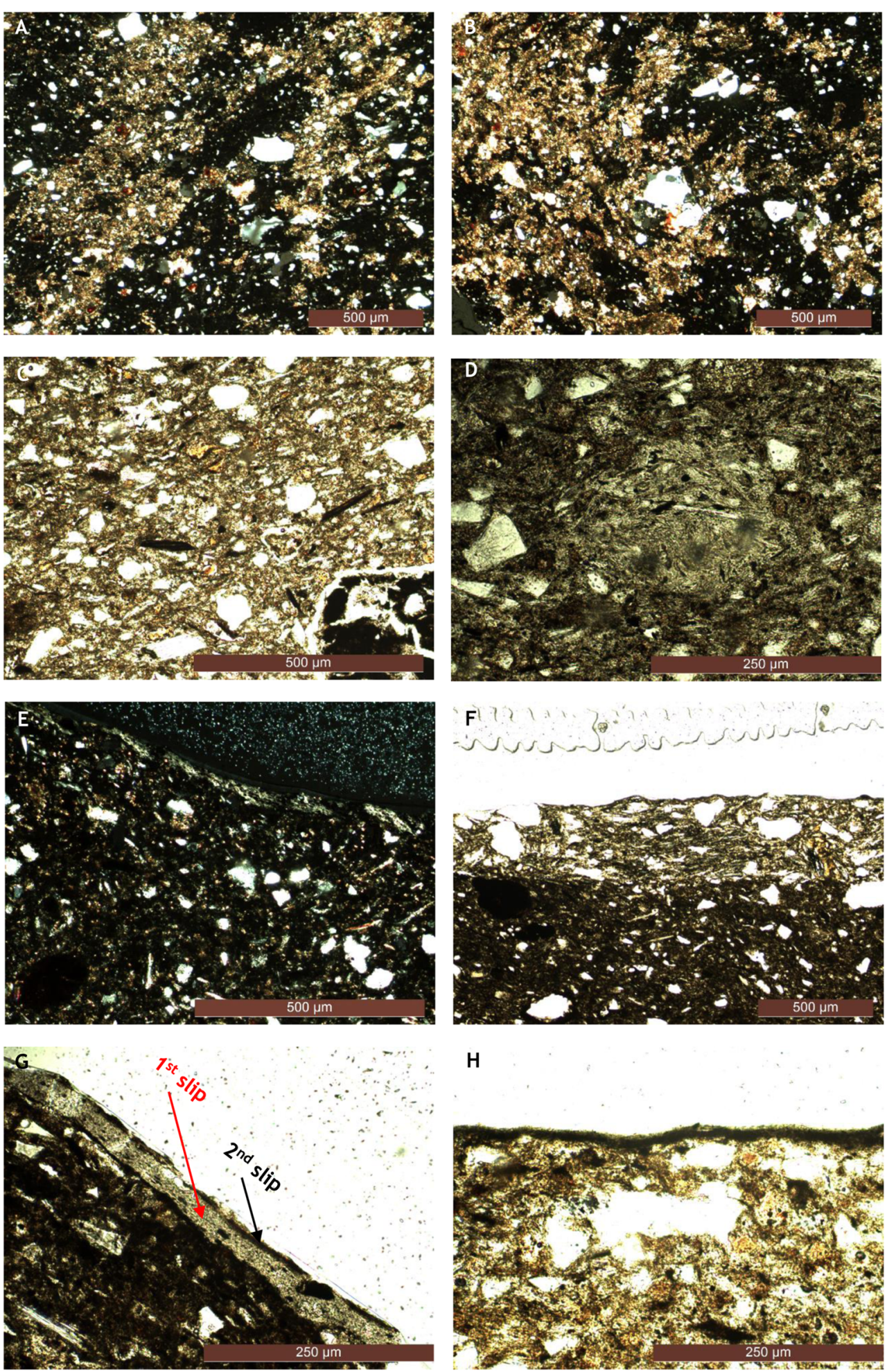

H

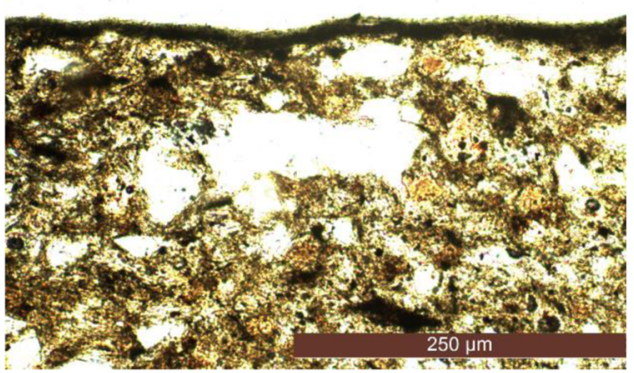

excluded. Indeed, the ESB is assumed to have mainly been produced around Aydın-i.e., the ancient city of Tralles in the Büyük Menderes Valley_on the basis of both archaeological and geochemical evidence (Sauer 1995a: 36-64; Schneider 2000; Ladstätter 2007: 208-209).

\section{Neutron activation analysis}

The 20 samples of Ephesos lamps were grouped and compared to 23 EGW and 47 ESB previously analyzed at the Atominstitut in Vienna as well as the data available from the 
Fig. 5 Thin-section

microphotographs under XP of Ephesos lamps representative of the first - (A) EPHL006 and (B) EHPL011 - and second minor groups-(C) EPHL013 and (D) EPHL019 - as well as petroloners EPHL015 (E), EPHL020 (F), and EPH241 (G, H)
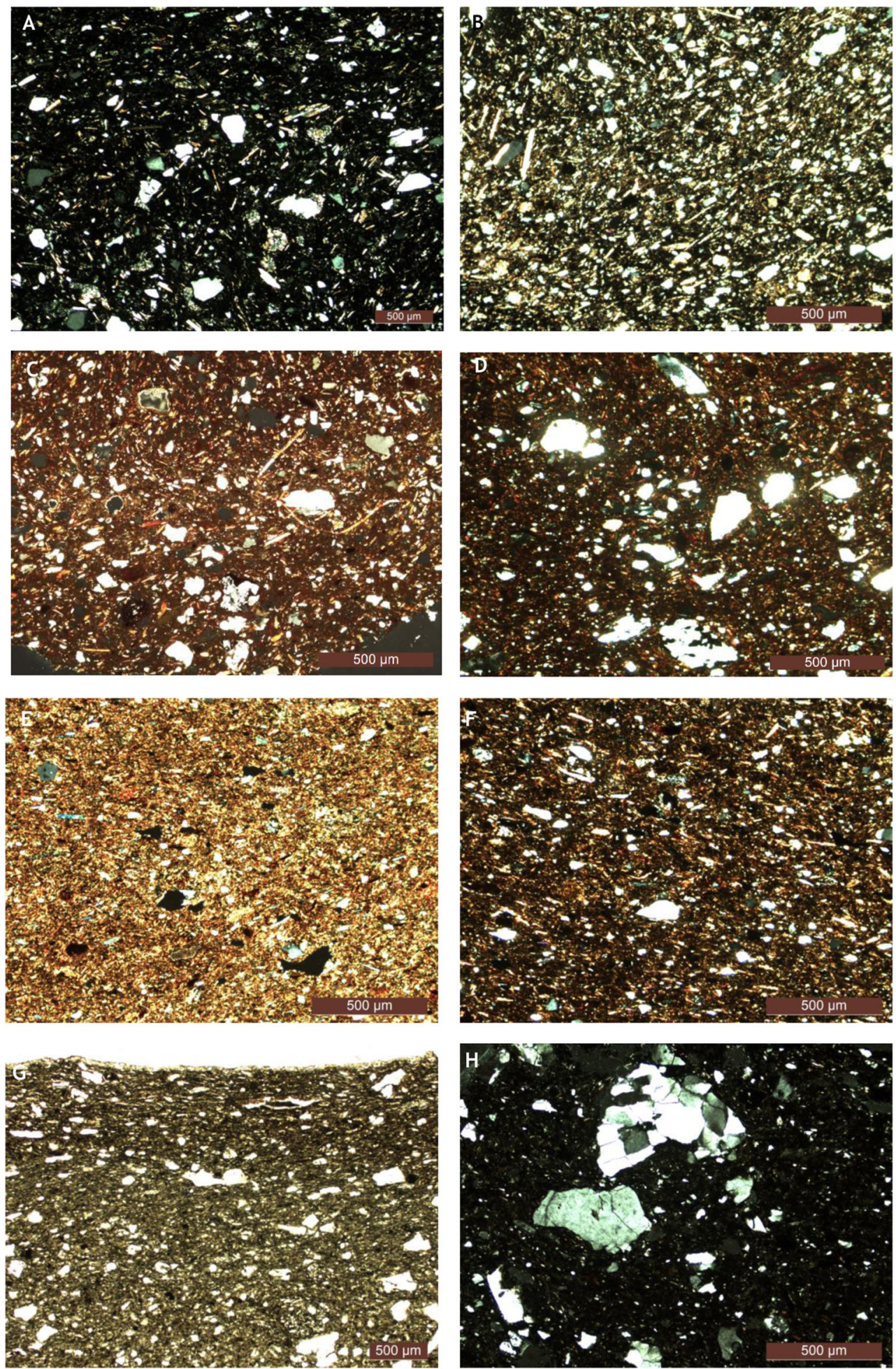

Bonn database on Ephesian ceramic productions (Kerschner et al. 2002; Akurgal et al. 2002; Kerschner 2007).

Statistical investigation of the full dataset performed to establish a grouping for the lamps showed that there is no chemical relation between the lamps and the ESB and that one large group containing both lamps and EGW could be established (the green circle on Fig. 7). This group is named Group03 and corresponds well with the so-called Group I published by Kerschner et al. (2002) and further refined in Kerschner (2007). Data from those publications - 15 samples represented by green squares on Fig. 7-clearly groups together with 15 lamps (green triangles) and 16 EGW (green dots) analyzed 
in Vienna and belonging to the most represented group among lamps, i.e., our Group03. The largest green square on Figure 7 represents the mean of Bonn "Group I," which also remarkably fits our Group03.

Further data from the above-mentioned publications and from Akurgal et al. (2002) was used to add an unclassified Ephesos lamp (EPHLAM20) to a large group of 27 samples belonging to Bonn "Group H" (blue squares on Fig. 7). Both groups, "Group I" and "Group H," represent the local fingerprint of Ephesos (Kerschner 2007). While "Group I" includes both archaic and Hellenistic vessels as well as molds for the production of mold-made relief bowls that Rogl assigned to ПАР workshop, "Group H" only contains archaic vessels (Kerschner et al. 2002: 193-198). Group03 (i.e., Group I) is distinguished by the lower and higher values of lanthanidesi.e., $\mathrm{La}, \mathrm{Ce}, \mathrm{Nd}, \mathrm{Sm}, \mathrm{Eu}, \mathrm{Tb}, \mathrm{Yb}$, and $\mathrm{Lu}-$ and $\mathrm{Rb}$ and $\mathrm{Ta}$, respectively. Though this still needs to be clarified in future publications, the low content of lanthanides is not surprising, since heavy minerals enriched in those elements - e.g., monazite, xenotime, allanite - rarely occur in the geological environment around Ephesos (Sauer 1995a and 1995b). The high values of alkali metals such as $\mathrm{Rb}$ could be instead related to the abundance of micas and/or feldspars as observed under the polarizing microscope. Table 1 reports the correspondence between Viennese and Bonn reference groups.

One lamp (EPHLAM1) and one EGW are chemically similar to each other but different from the above-mentioned groups and fall into our Group05 (pink dot and triangle on Fig. 7). The remaining three lamps (EPHLAM8, EPHLAM18, and EPHLAM19) could not be grouped at all and are thus to be considered as chemical loners. Analytical data for the 20 Ephesos lamp samples as well as the group means for the three groups containing Ephesos lamps can be found in Tables 4 and 5 .

Although not coeval with Ephesos lamps, we also compare our NAA data with those obtained from Late Roman lamps from Rhodes, which were attributed to different areas of the western coast of Asia Minor, i.e., southern Aeolis, northern Ionia, and southern Ionia (Hein and Kilikoglou 2017: 651657). No match has been found with our local groups 03,04 , and 05. This also pertains to Hein and Kilikoglou's group A1, which fits with Klazomenai-i.e., group SMYR-E in Akurgal et al. 2002 and Kerschner and Mommsen 2009-but shows affinities with Ephesos according to Katsioti (2017: 662).

\section{Discussion of the results}

Although this remains to be further investigated on a larger set of samples, both thin-section and NAA analyses point to similar trends, namely the occurrence of a predominant local group shared with other coeval wares and the presence of a few loners (Table 1). Apart from a very few exceptions (i.e., 3 
Fig. 6 Thin-section

microphotographs under XP of mold-made relief bowls (A, B), EGW (C), ESB (D) fired clay samples within the Küçük Menderes Valley (E-H)
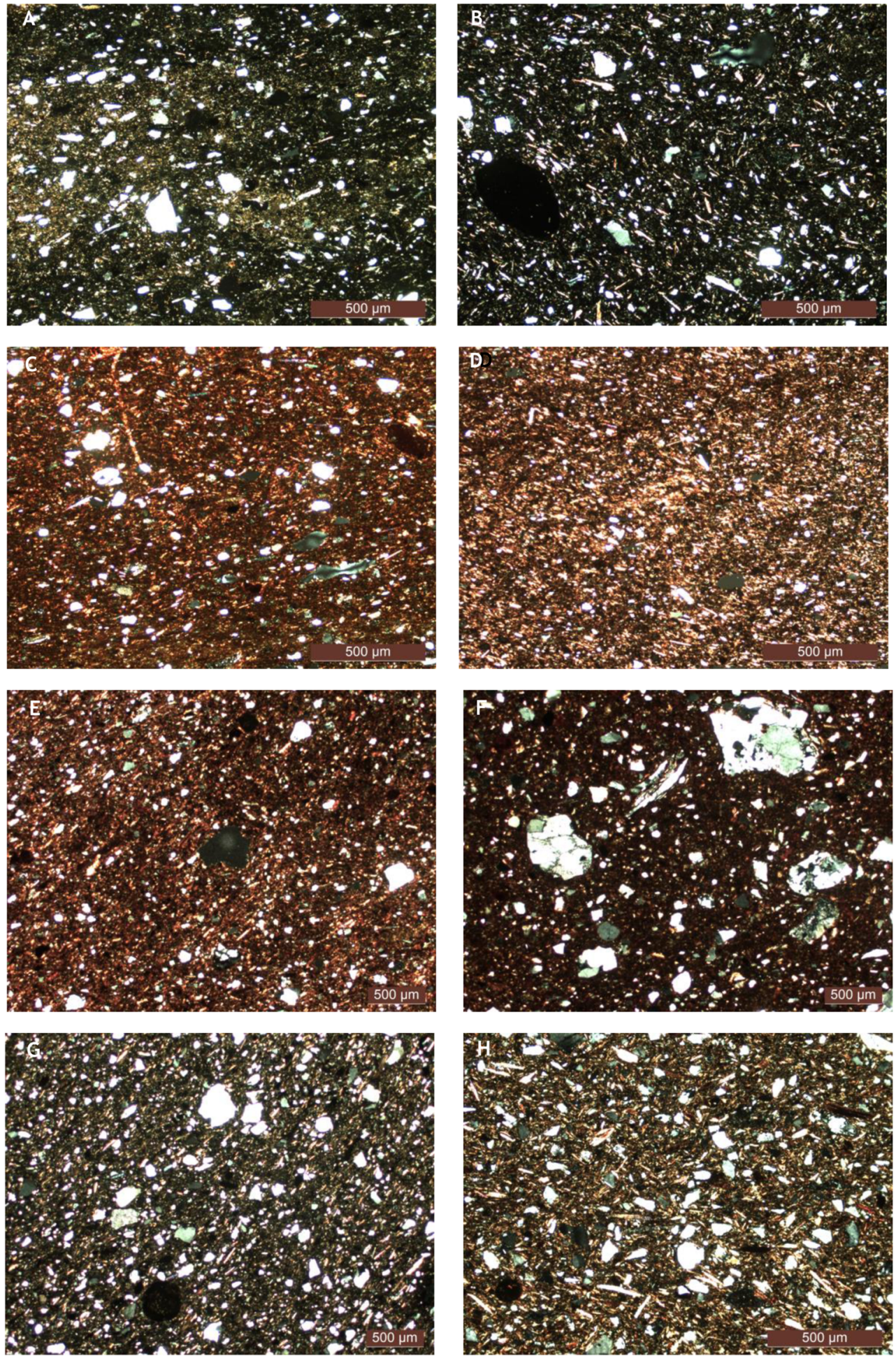

out of 17 cases), the NAA and petrographic predominant group - respectively mentioned as NAA Group03 and major group - widely match each other, as they include the same samples. The correlation between NAA and petrographic results decreases when considering loners: two NAA loners (EPHLAM8, EPHLAM18) belong to the major petro-group, while NAA Group03 includes one petrographic loner (EPHLAM7). Among petro-loners, EPHLAM7 is the most akin to the major petrographic group, from which it differs only by the prevalence of feldspars over micas (Tables 2 and 3). As the dilution approach applied to NAA data strongly reduces the signal of inclusions, we can assume that 


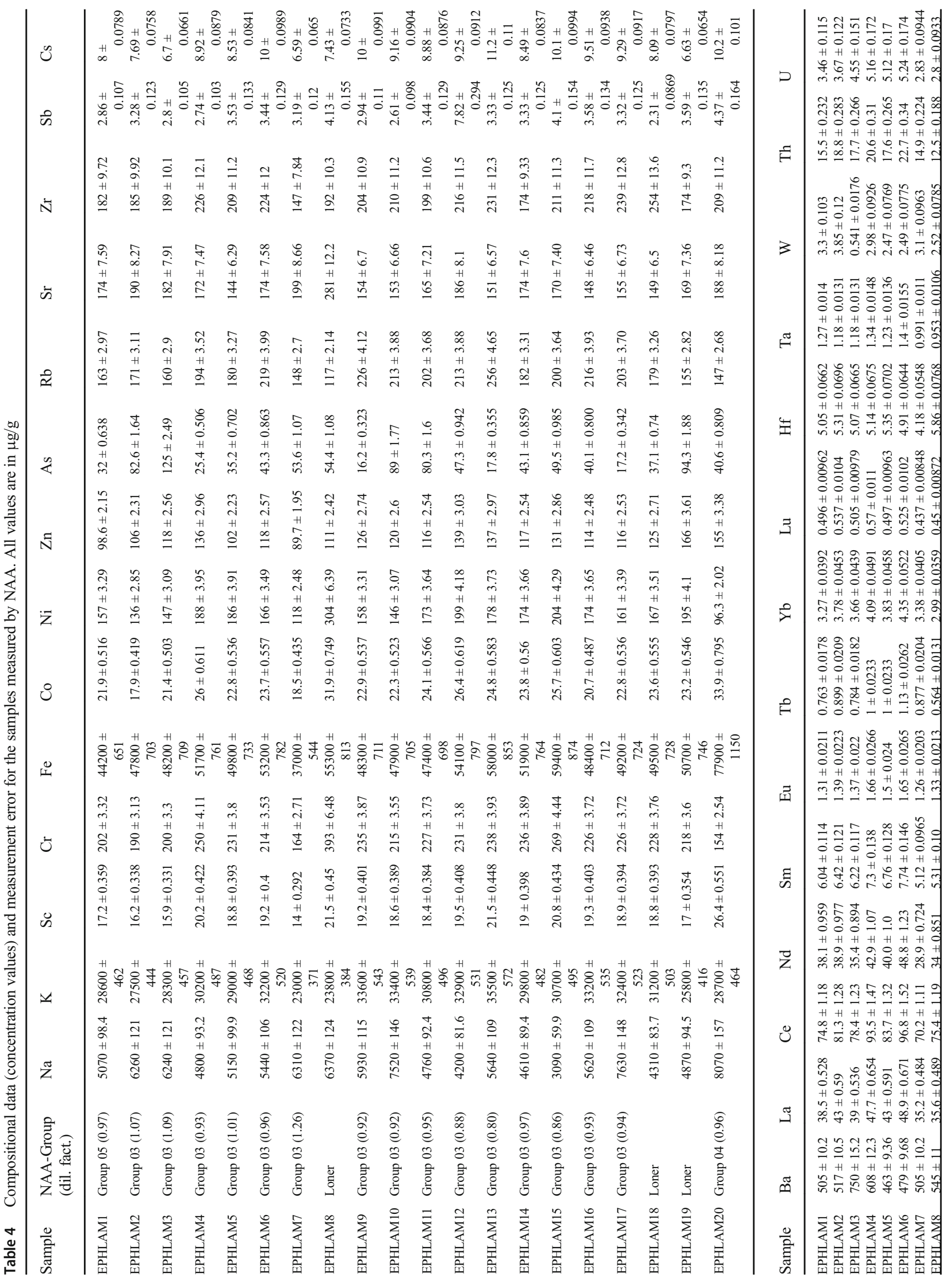




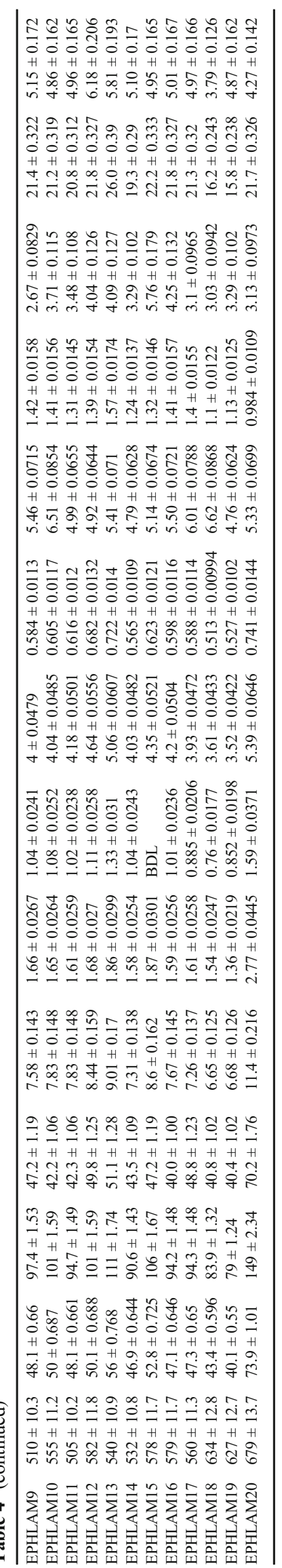

EPHLAM7 was produced with similar clay sources but different paste preparations compared to most of the lamps. By the same principle, the NAA loners EPHLAM8 and EPHLAM18 indicate instead the use of distinct clay sources, although their inclusions do not qualitatively and quantitatively differ from that observable in the majority of lamps. Nevertheless, both thin-section petrography and NAA concur in differentiating EPHLAM19 and EPHAML20 from all the other lamps.

In general, thin-section petrography evidences a higher variability compared to NAA: nine recipes including three petrogroups and six petro-loners were identified under the microscope vs. the three groups and three loners that emerged from NAA. This is probably because technological aspects such as finishing and firing - which do not anyhow affect the concentration of trace elements - were considered as distinguishing criteria under the microscope. A further aspect that might have affected the variability is the number of samples, which is significantly higher for thin-section petrography ( 45 vs. 20 for NAA). In fact, if we look only at the 19 samples analyzed through both methods, the number of petrographic recipes decreases from nine to four and becomes thus less than those identified via NAA. However, as many other coeval wares petrographically akin to Ephesos lamps repeatedly fall into only two well-established NAA groupings, we would not expect an increased geochemical variability by adding new lamp samples. At any rate, the NAA results evidence a noticeable constancy and continuity in the exploitation of supply sources in Ephesos, which dates back at least to the Archaic times. A further result distinguishing thin-section petrography from NAA is the affinity of isolated oxidizing fired lamps with ESB. In order to interpret this mismatch in terms of raw material procurement and processing, further NAA analyses have to be applied to fine-grained oxidizing fired variants of lamps in the future. In order to establish a chronological sequence in the use and processing of raw materials, we designed a seriation table that relates petro- and NAA groupings with chrono-types (Fig. 8). The table also includes the information on decorative motifs, workshop attributions, and firing atmospheres as factors that can affect the nature of ceramic recipes as well. The predominant compositional group emerging both from petrographic and NAA analyses includes specimens from every typological group, though the earliest group 1 significantly predominates over the later groups 2,5 , and 6 . All the exemplars belonging to this predominant compositional group were fired under reducing atmospheres and decorated with a wide spectrum of motifs, such as elongated petals and heart-shaped, lotus-shaped, lanceolate, ovoid, and oak leaves. All the lamps attributed to the Asklepiades workshop, whether on the basis of decorative style or signatures, fall into this predominant compositional group. The few remaining unattributed lamps (four out of 12 samples) belong to later types ( 5 and 6) and are generally decorated with oval and elongated 
Fig. 7 Principal component analysis (PCA) of the dilutioncorrected data. Group03 and Group 05 contain both grey plates and lamps, while Group04 shows a single lamp that fits the data in the literature. Group means of "Group I" and "Group H" are taken from Kerschner (2007) to provide a visual reference point. Ellipses depict 95\% confidence intervals for the groups; in case of Group03 and Group04 this includes literature data, thus providing our suggested grouping for "Group I" and "Group H," respectively

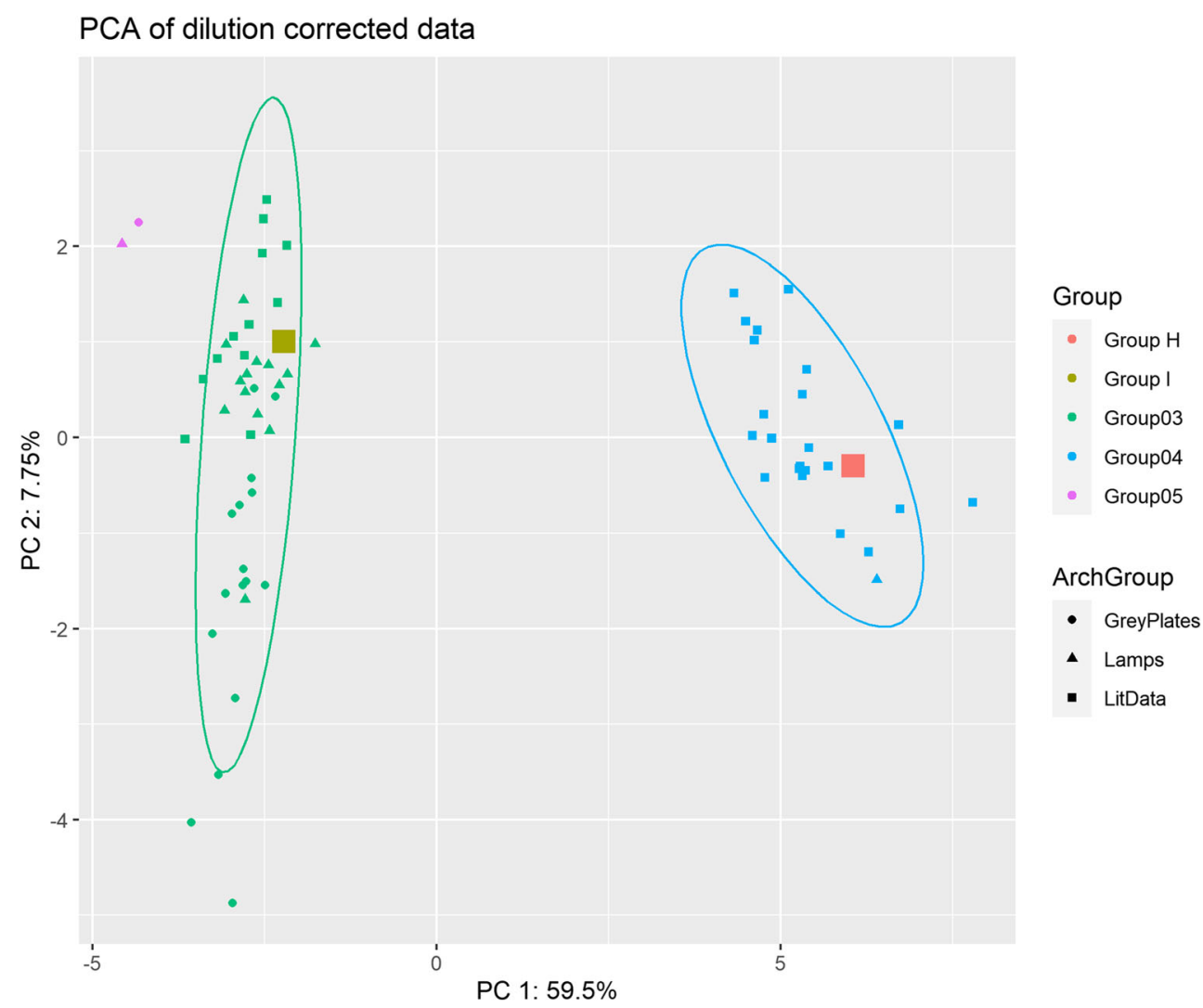

leaves. As already stated, both methods could not be integrated on all the samples for a variety of reasons. Three samples could fall into the predominant NAA/petro-group once this integration occurs, as they belong either to the major petrogroup (e.g., EPH242, EPH243) or to the major NAA group (e.g., EPHLAM5). EPHLAM5 belongs to the first typological group, bears a figural decoration depicting Silen and, like the samples classified into the predominant NAA/petro-group, was fired under reducing atmospheres. The same firing procedures characterize EPH242 and EPH243, which, however, belong to the latest type. EPH243 is in particular decorated with a row of petaled rosettes.

Petrographic and NAA loners are exclusively related to later types 5 and 6, usually fired under oxidizing atmospheres and decorated with palmettes, rosettes, or double spirals. In general, oxidizing fired variants are distinguished by a higher compositional variability: when they are not loners, they belong to small-sized reference groups, such as the second minor petro-group related to lamps of type 6 decorated with triple berries and the so-called Ionian Kyma. The first minor petrogroup includes instead reducing fired variants of the earliest type decorated with maple leaves and wine stalks. Interestingly, the only exemplar with the ATP monogram here analyzed (EPHLAM7) shares the same NAA group-i.e., the same clay sources - with the exemplars of the Asklepiades workshop but exhibits distinct petrographic features-i.e., paste preparation — which make it a petro-loner.
The seriation table reported in Figure 8 evidences changes at the transition to type 5 , i.e., between the third quarter of the $2^{\text {nd }}$ c. BCE. and the early $1^{\text {st }}$ c. BCE. These changes occurred at a compositional, stylistic, and technological level: new sources and recipes were used, leading to a higher compositional variability, which corresponds to the emergence of a wider spectrum of decorative motifs and the development of oxidizing fired variants.

\section{Conclusions}

The Ephesos lamps taken under consideration here were produced according to variable raw material procurement patterns, paste preparation modes, surface treatments, and firing procedures within the Küçük Menderes Valley. In combination with the variety of decorative motifs and preserved signatures (Giuliani 2001), this points to a network of local/ regional workshops rather than to a single-unit production model. Nonetheless, one group clearly predominates when we compare petrographic and NAA data. This includes lamps related to different workshops, types, and decorative motifs as well as other coeval wares, such as EGW and mold-made relief bowls. In other words, a significant part of the Late Hellenistic ceramic production shared the same raw materials and paste preparation. Despite similarities in decorative motifs, previous studies have questioned the probability of a 


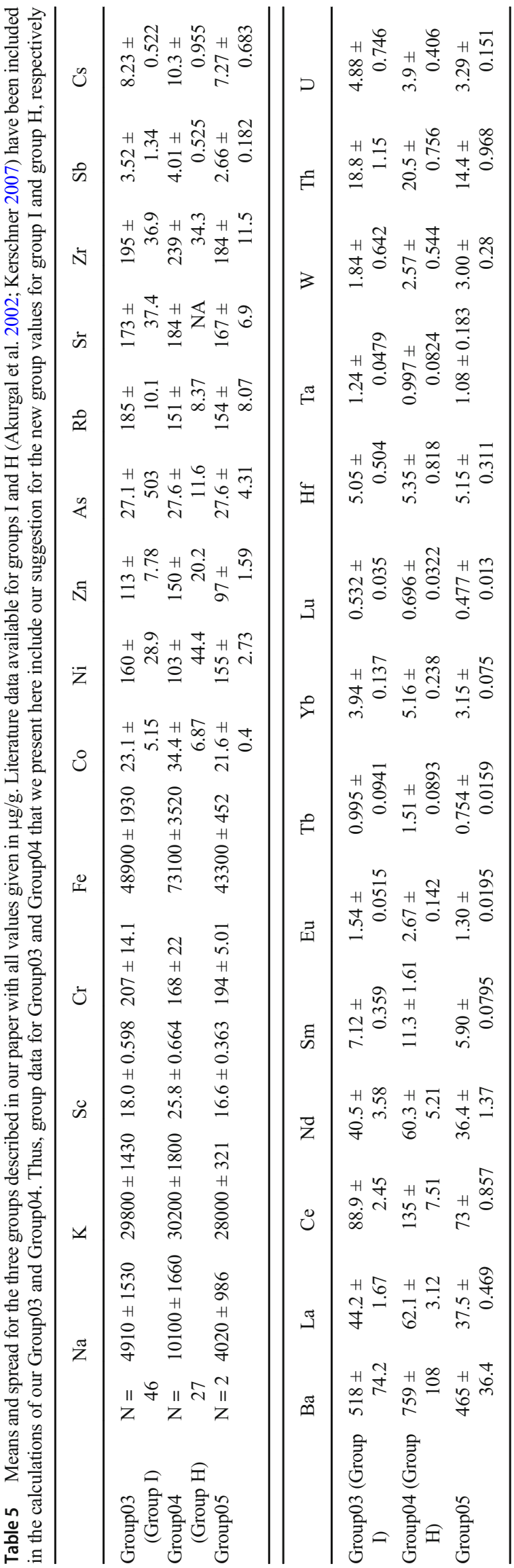

production of relief mold-made bowls and Ephesos lamps in the same workshops due to technological (e.g., quality of the slip) and chronological criteria (Ladstätter and Waldner in press). Thus, the predominance of one compositional group across different wares would rather suggest a number of distinct production units using the same clay source and following more or less the same generic recipe. Advancing this interpretation, one can even imagine that the procurement and processing of raw materials were undertaken either communally through forms of co-operation-which could also include shared facilities such as large clay-processing basinsor by an additional labor force possibly operating beyond single workshops.

Though this needs to be further corroborated on a larger set of samples, the lower and higher variability of NAA and petrographic data could indicate that raw materials collected from the same sources were processed in different ways, which were sometimes workshop-specific such as in the case of the ATP workshop. Significantly more obvious is the higher variability of surface treatments (e.g., clay slipping) in comparison to other technical stages. These fluctuations in standardization along the manufacturing process might indicate a division of labor tasks within the chaîne opératoire of Ephesos lamps. As stressed by Cuomo di Caprio (2007: 324) for some Campana $\mathrm{C}$ plates from Morgantina, those who were in charge of shaping vessels did not necessarily deal with either the surface finishing and slipping or with the firing process. Concerning Ephesos lamps, it remains nonetheless unclear why in such a cultural koine the technical knowledge necessary to obtain vitrified slips and thus better-suited end products, both in functional and aesthetic terms, was not transmitted as widely as other parameters.

The centralized strategies of raw material procurement and the division of tasks along the chaîne opératoire fit well with the hypothesis of highly specialized workshops supported by the city to fill the demand of an increased local and regional market (Ladstätter 2007; Ladstätter and Waldner in press). The closest model of production assumable is an initial nucleated workshop industry, through which individual workshops cluster around shared facilities and labor force, also not specialized, in order to optimize the productivity of mold-made ware. A different picture clearly emerges from oxidizing fired variants despite the reduced number of samples analyzed so far. These variants differ from the more widespread reducing ones by the production modes, places, and organization. Distinct and quite variable strategies in raw materials procurement and modes of paste preparation, surface treatments, and firing were indeed employed. Unfortunately, the selection of samples from a limited number of contexts in such a huge city does not allow us to discuss our results in terms of customers' preferences. However, we would not expect significant differences in relation to distinct contexts of provenance, as types and sub-types invariably occur within the city and our 


\begin{tabular}{|l|l|c|c|c|}
\hline & Type 1 & Type 2 & Type 5 & Type 6 \\
\cline { 2 - 6 } & First minor petro-group & 1 & & \\
\hline Major NAA group & 1 & 1 & 2 & 3 \\
\hline Predominant NAA/petro-group & 6 & & 1 & 2 \\
\hline NAA loners & & & 1 & 2 \\
\hline Petro loners & & & & 2 \\
\hline Major petro-group & & & 2 \\
\hline Second minor petro-group & & & \\
\hline \multirow{2}{*}{}
\end{tabular}

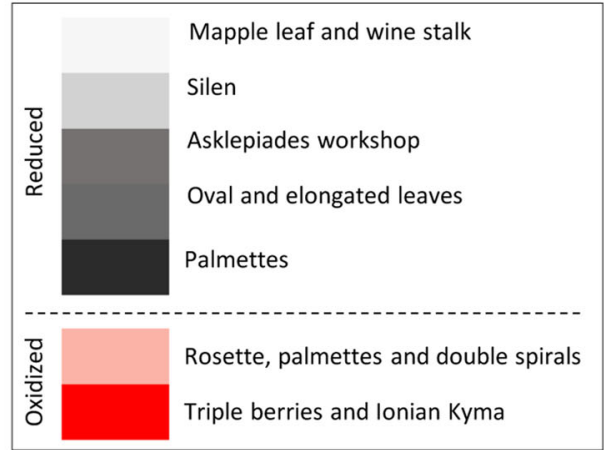

Fig. 8 Seriation table correlating chrono-typology, NAA, and petrographic groups as well as decorative motifs and signatures. Only samples with a clear typological attribution are reported: EPHL011 for the first minor petro-group; EPHLAM5 for the major NAA group; EPHLAM1, EPHLAM2, EPHLAM3, EPHLAM4, EPHLAM9, EPHLAM10, EPHLAM11, EPHLAM11, EPHLAM12, EPHLAM13, EPHLAM14, EPHLAM15, and EPHLAM16 for the predominant NAA/petro-group; EPHLAM 8, EPHLAM 18, and EPHLAM19 for

petrographic recipes, including loners, are represented in almost each context investigated here.

At a diachronic level, the correlations between chronotypological and compositional groups evidence a general continuity in the raw material procurement patterns and paste preparation modes. The distribution of the main compositional group across the various types indicates a well-established tradition of at least 100 years ranging from the earliest exemplars of the mid $2^{\text {nd }} \mathrm{c}$. BCE to the Howland 49A type produced until the Late Augustan times. Despite the general continuity, slight fluctuations are observable in the course of time. By the late $2^{\text {nd }} \mathrm{c}$. $\mathrm{BCE}$, the incidence of the predominant group decreases, while new supply sources and paste preparation are established. Intriguingly, in the latest phases, typologically unidentified lamps appear, i.e., typological singletons. The highest variability of the latest phases in terms of both typological and compositional features suggests that an increased number of workshops were producing lamps in the region. As this variability is partially related to oxidizing fired variants, the finest variants of which show petrographic affinities with the ESB, this change could also indicate a gradual transfer of potting activities towards areas providing better-suited clay sources such as the Büyük Menderes Valley. ${ }^{3}$

Though preliminary, our results shed new light on the organization of the pottery production at Ephesos in a period when local ceramics reached an unprecedented level in terms of quality and distribution (Ladstätter 2007; Ladstätter and Waldner in press). Furthermore, they represent an important step towards the systematization of compositional data aimed

\footnotetext{
${ }^{3}$ The clay deposits around Aydın in the Büyük Menderes Valley are still widely exploited today for the production of ceramic vessels and bricks due to their excellent properties in terms of plasticity, workability and texture.
}

NAA loners; EPHL015, EPH241, and EPHLAM07 for petro-loners; EPH242 and EPH243 for the major petro-group; and EPHL19 and EPHL21 for the second minor petro-group. The samples for which the petrographic and NAA results did not coincide (e.g., EPHLAM7, EPHLAM8, and EPHLAM18) are not reported. The red vertical dashed line indicates changes by the late $2^{\text {nd }} \mathrm{c}$. BCE in the raw material procurement and processing. The correlation with decorative motifs has to be taken as a general trend.

at reconstructing the network of workshops and exchanges around Ephesos. Future aims consist in further characterizing some steps of the operational sequence, such as, for instance, surface finishing and firing, as well as enlarging the sampling to Ephesos lamps found across the Mediterranean in order to assess the distribution scale of the single local/regional workshops and to identify their Mediterranean-wide imitations.

Methodologically, this study further evidences the need to integrate different datasets for the identification of workshops. Separately, the characterization of raw materials and the classification of objects into typo-chronological and stylistic categories are not sufficiently reliable to support a workshop attribution. We showed that different workshops can share similar raw material procurement patterns, paste preparation modes, and decorative motifs, while other procedures like surface finishing might strongly vary within the same production unit. In this framework, even workshop signatures become a more fluid evidence hiding the underlying complex network of people and labor. If the identification of Late Hellenistic workshops still needs much investigation, the integration of NAA and thin-section petrography allowed us to establish a solid reference group, which will aid in clarifying the distribution radius of the Ephesian ceramic market at its apogee.

Acknowledgements We would like to thank Sabine Ladstätter for providing access to the materials and supporting our work, from the sampling to the interpretation of data. We are thankful to Alice Waldner for her very constructive comments on the paper and more specifically on the production organization of Ephesian Late Hellenistic ceramics, as well as to Helmut Schwaiger and Bettina Schwarz for having helped us to recover data on the materials sampled by previous scholars. We are indebted to the whole Ephesos team for making our work in Ephesos and Vienna not only possible but richer on many levels. We are thankful to the two anonymous reviewers for the valuable suggestions on our manuscript. 
Author contribution All authors contributed to the study conception and design. PF secured the funds for this work through the Austrian Archaeological Institute; collected the samples in Ephesos; performed thin-section petrography; wrote the part related to the petrographic results and geological setting as well as a first draft of the discussion and conclusion, which all authors commentated; and edited the final draft. MU selected the samples based on the typological and contextual study she performed for this work and wrote the introduction as well as the part related to the archaeological context and ceramic repertoire. All authors contributed to the part on materials and methods. NAA was performed by JHS who also processed and wrote up the results. RS provided expertise on the geological background and ceramic petrography.

Open Access This article is licensed under a Creative Commons Attribution 4.0 International License, which permits use, sharing, adaptation, distribution and reproduction in any medium or format, as long as you give appropriate credit to the original author(s) and the source, provide a link to the Creative Commons licence, and indicate if changes were made. The images or other third party material in this article are included in the article's Creative Commons licence, unless indicated otherwise in a credit line to the material. If material is not included in the article's Creative Commons licence and your intended use is not permitted by statutory regulation or exceeds the permitted use, you will need to obtain permission directly from the copyright holder. To view a copy of this licence, visit http://creativecommons.org/licenses/by/4.0/.

\section{References}

Akurgal M, Kerschner M, Mommsen H, Niemeier W-D (2002) Töpferzentren der Ostägäis. ErghÖJh 3. ÖAI, Vienna

Bailey DM (1975) A Catalogue of the Lamps in the British Museum I. Greek, Hellenistic, and Early Roman Pottery Lamps. British Museum Publications, London

Beier T, Mommsen H (1994) Modified Mahalanobis filters for grouping pottery by chemical composition. Archaeometry 36:287-306. https://doi.org/10.1111/j.1475-4754.1994.tb00971.x

Broneer O (1930) Terracotta Lamps, Corinth IV, 2. Harvard University Press, Cambridge Terracotta Lamps

Bruneau P (1965) Exploration archéologique de Délos 26. Les lampes. De Boccard, Paris

Bussière J, Lindros Wohl B (2017) Ancient lamps in the J. Paul Getty Museum. J. Paul Getty Museum, Los Angeles http://www.getty. edu/publications/ancientlamps

Buxeda I Garrigós J, Jones RE, Kilikoglou V, Levi ST, Maniatis Y, Mitchell J, Vagnetti L, Wardle K, Andreou S (2003) Technology transfer at the periphery of the Mycenaean world: the cases of Mycenaean pottery found in Central Macedonia (Greece) and the plain of Sybaris (Italy). Archaeometry 45(2):263-284. https://doi. org/10.1111/1475-4754.00108

Chrzanovski L (2020) "Ephesos lamps": debunking mythologies by using the most recent and important contexts in the whole Hellenistic world. In: Chrzanovski L, Ugarković M (eds) A "Globalized" Antiquity: Imports and Local Adaptations of Mainstream Lamp Types. The Examples of "Ephesos Lamps" in the Mediterranean and Black Sea and of Roman "Standard" Types during the Early Imperial Period in Gaul. Acta of the 6th and 7th round tables of the ILA (Athens, 15th of November 2019 and Geneva, 17th of February 2020). Serta Instituti Archaeologici 16. Institute of Archaeology, Zagreb, pp. 19-50

Cuomo di Caprio N (2007) Ceramica in archeologia 2. Antiche tecniche di lavorazione e moderni metodi di indagine, 2nd edn. L'Erma di Bretschneider, Roma
Çakmakoğlu A (2007) Pre-Neogene Tectonostratigraphy of Dýlek Peninsula and the Area Surrounding Söke and Selçuk. Bull Miner Res Explor 135:1-17

De Bonis A, Germinario C, Grifa C, Guarino V, Langella A, Morra V, Ferrara B, Munzi P, Serritella A (2017) The black-glaze production in the Tyrrhenian coast of southern Italy: A review of the archaeometric data, Forum Archaeologiae 83/VI https:/homepage. univie.ac.at/elisabeth.trink1/forum/forum0617/83naples.htmS

Drougou S (2012) Clay lamps in ancient Macedonia during the Hellenistic period. In: Drougou S, Touratsoglou G (eds.) Themata tēs ellēnistikēs keramikēs stēn archaia Makedonia. Athens, pp. 86106

Gassner V (1997) Das Südtor der Tetragonos-Agora: Keramik und Kleinfunde. Forschungen in Ephesos 13.1.1. Verlag der österreichischen Akademie der Wissenschaften, Vienna

Giuliani A (2001) Untersuchungen zu Ephesos-Lampen an Beispielen aus der Werkstatt des Asklepiades. In: Krinzinger F (ed) Studien zur hellenistischen Keramik in Ephesos. ErghÖJh 2. ÖAI, Vienna, pp 45-49

Giuliani A (2004) Namenssignaturen hellenistischer Lampenwerkstätten. ÖJh 73:137-157

Giuliani A (2005a) Lampenmatrizen hellenistischer Zeit aus ephesischer Produktion im Rijksmuseum van Oudheden, Leiden. ÖJh 74:73-83

Giuliani A (2005b) Hellenistische Matrizenlampen aus Ephesos. In: Chrzanovski L (ed) Lychnological Acts 1. Actes du Ier Congrès International d'études sur le luminaire antique (Nyon - Genève, 29.IX - 4.X. 2003). Monographies Instrumentum 31. Mergoil, Montagnac, pp 139-142

Giuliani A (2008) The exports of Hellenistic Ephesian lamp-workshops and their influence on the local production in the East. In: Roman CA, Gudea N (eds) Lychnological Acts 2. Trade and Production of Lamps from Prehistory until the Middle Age. Editura Mega, ClujNapoca, pp 91-95

Giuliani A (2011) New aspects on the Chronology of Hellenistic lamps from Ephesos. 7th Scientific Meeting on Hellenistic Pottery, Aigio

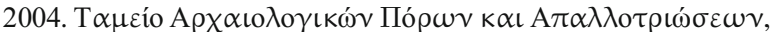
Athens, pp. 533-538

Giuliani A, Rogl C (2002) Ephesische Töpferwerkstätten - ihre Töpfer und ihre Produkte. In: Asamer B, Höglinger P, Reinholdt C, Smetana R, Wohlmayr W (eds) Temenos. Festgabe Florens Felten und Stefan Hiller. Phoibos, Vienna, pp 71-74

Hein A, Kilikoglou V (2017) E.1. Analysis of Late Roman Lamps from Rhodes. In: Katsioti A (ed) The Lamps of Late Antiquity from Rhodes 3rd-7th centuries AD. Archaeopress Archaeology, Oxford, pp 651-657

Hintermann T (2016) Graue Ware mit schwarzem Überzug aus Ephesos. Unpublished $\mathrm{PhD}$ thesis, University of FZürich, Zürich

Howland RH (1958) Athens. The Athenian Agora. Results of Excavations Conducted by the American School of Classical Studies at Athens Vol. IV. Greek Lamps and Their Survivals. The American School at Athens, Princeton

James S (2020) An Update on Ephesos-type Lamps from Corinth. In: Chrzanovski L, Ugarković M (eds) A "Globalized" Antiquity: Imports and Local Adaptations of Mainstream Lamp Types. The Examples of "Ephesos Lamps" in the Mediterranean and Black Sea and of Roman "Standard" Types during the Early Imperial Period in Gaul. Acta of the 6th and 7th round tables of the ILA (Athens, 15th of November 2019 and Geneva, 17th of February 2020). Serta Instituti Archaeologici 16. Institute of Archaeology, Zagreb, pp. 51-66

Kajzer M (2013) The 'Ephesian' terracotta oil lamps from the Agora of Nea Paphos, Studies in Ancient Art and Civilization 17. Instytut Archeologii Uniwersytetu Jagiellońskiego, Krakow, pp. 249-254.. https://paphos-agora.archeo.uj.edu.pl/documents/5871239/ bf0a3ba2-446e-484f-a12d-25be313e07b6 
Kajzer M (2016) To light Antiquity. Perspectives for research on clay oil lamps from the Agora in Nea Paphos, Cyprus. In: Bodzek J (ed) Studies in ancient art and civilization 20. Jagiellonian University, Kraków, pp 115-124

Kajzer M (2017) The integrated approach to research on oil lamps from Nea Paphos, Cyprus. Poster at the international colloquium Nea Paphos and western Cyprus. New Archaeological and Historical Perspectives. Kouklia \& Paphos, 11th-15th October 2017

Katsioti A (2017) The Lamps of Late Antiquity from Rhodes 3rd-7th centuries AD. Archaeopress Archaeology, Oxford

Kerschner M (2007) Das Keramikbild von Ephesos im 7. und 6. Jh. v. Chr. Mit einem Beitrag von Hans Mommsen und Alexander Schwedt. In: Justus C, von Graeve V, Niemeier WD, Zimmermann K (eds) Frühes Ionien. Eine Bestandsaufnahme, Milesische Forschungen 5. Von Zabern, Mainz am Rhein, pp 221-246

Kerschner M, Mommsen H, Rogl C, Schwedt A (2002) Die Keramikproduktion von Ephesos in griechischer Zeit. Zum Stand der archäometrischen Forschung. ÖJh 71:189-206

Koralay OE, Candan O, Akal C, Dora OÖ, Chen F, Satir M, Oberhänsli R (2011) The Geology and Geochronology of the Pan-African and Triassic Metagranitoids in the Menderes Massif, Western Anatolia, Turkey. Mineral Res Expl Bull 142:69-119

Ladstätter S (2005) Keramik. In: Thür H (ed) Hanghaus 2 in Ephesos: Die Wohneinheiten 4. Baubefund, Ausstattung, Funde, Forschungen in Ephesos 8.6. ÖAW, Vienna, pp 230-265

Ladstätter S (2007) Mode oder politisches Manifest? Überlegungen zur Übernahme römischen Formenguts in der frühkaiserzeitlichen Keramik von Ephesos. In: Meyer M (ed) Neue Zeiten - Neue Sitten. Zu Rezeption und Integration römischen und italischen Kulturguts in Kleinasien, Wiener Forschungen zur Archäologie 12. Phoibos, Vienna, pp 203-219

Ladstätter S (2016) Hafen und Stadt von Ephesos in hellenistischer Zeit. ÖJh 85:233-272

Ladstätter S (2010) Keramik. In: Krinzinger F (ed) Hanghaus 2 in Ephesos: Die Wohneinheiten 1 und 2. Baubefund, Ausstattung, Funde, Forschungen in Ephesos 8.8. ÖAW, Vienna, pp 172-279 530-587

Ladstätter S, Waldner A (in press) Ephesos - Production and Consumption Centre. In: Zhuravlev D, Schlotzhauer U (eds) Late Hellenistic and Roman Tableware in the Black Sea, Eastern Mediterranean and in the West (150 BC-250 AD). Eurasia Antiqua

Miltner F (1937) Das Coementerium der Sieben Schläfer, Forschungen in Ephesos 4.2. ÖAW, Vienna

Mitsopoulos-Leon V (1985) Töpferateliers in Ephesos. In: Alzinger W (ed) Pro arte antiqua. Festschrift für Hedwig Kenner 2. Koska, ÖAI, Vienna, pp 247-251

Mitsopoulos-Leon V (2007) Die Lampen. In: Mitsopouls-Leon V, Lang Auinger C (eds) Die Basilika am Staatsmarkt in Ephesos, Forschungen in Ephesos 2.3. ÖAW, Vienna, pp 64-11

Mommsen H, Sjöberg BL (2007) The Importance of the 'Best Relative Fit Factor' when evaluating elemental concentration data of pottery demonstrated with Mycenaean sherds from Sinda, Cyprus. Archaeometry 49:359-371

Okay AI (2001) Stratigraphic and metamorphic inversions in the central Menderes Massif. A new structural model. Int J Earth Sci 89:709-727

Peloschek L (2015) Archaeometric analyses of ceramic household inventories: current research in Ephesos and at Çukuriçi Höyük. In: Özme A (ed) 31. Arkeometri sonuçları toplantısı, Erzurum, pp 253-260

Rice PM (1987) Pottery Analysis: A Sourcebook. The University of Chicago Press, Chicago

Rogl C (2001) Eine Vorschau zu den reliefverzierten Trinkbechern der ephesischen Monogramm-Werkstätte. In: Krinzinger F (ed) Studien zur hellenistischen Keramik in Ephesos, ErghÖJh, vol 2. ÖAI, Vienna, pp 99-111
Rogl C (2014) Mouldmade Relief Bowls from Ephesos - The Current State of Research. In: Guldager Bilde P, Lawall ML (eds) Pottery, Peoples and Places. Study and Interpretation of Late Hellenistic Pottery, Black Sea Studies 16. Aarhus University Press, Aarhus, pp 13-139

Sauer R (1995a) Produktionszentren späthellenistischer und römischer Keramik an der Westküste Kleinasiens: Teil 1. Unpublished report, Vienna.

Sauer R (1995b) Produktionszentren späthellenistischer und römischer Keramik an der Westküste Kleinasiens: Teil 2. Unpublished report, Vienna.

Schneider G (2000) Chemical and mineralogical studies of Late Hellenistic to Byzantine pottery production in the eastern Mediterranean. RCRFActa 36:525-536

Seiterle G (1982) Die Hauptstadttor von Ephesos. Antike Kunst 25(2): $145-149$

Sheiko I (2020) Asia Minor lamps from Olbia: production and trade issues. In: Chrzanovski L, Ugarković M (eds) A "Globalized" Antiquity: Imports and Local Adaptations of Mainstream Lamp Types. The Examples of "Ephesos Lamps" in the Mediterranean and Black Sea and of Roman "Standard" Types during the Early Imperial Period in Gaul. Acta of the 6th and 7th round tables of the ILA (Athens, 15th of November 2019 and Geneva, 17th of February 2020). Serta Instituti Archaeologici 16. Institute of Archaeology, Zagreb, pp. 135-168

Sokolicek A (2009) Zwischen Stadt und Land: Neues zum Magnesischen Tor in Ephesos Erste Ergebnisse. ÖJh 78:321-352

Sterba JH (2018) A workflow for Neutron Activation Analysis of archaeological ceramics at the Atominstitut in Vienna, Austria. J Radioanal Nucl Ch 316:753-759

Thér R (2014) Identification of pottery firing structures using the thermal characteristics of firing. Archaeometry 56:78-99. https://doi.org/10. 1111/arcm. 12052

Ugarković M (2016) Light from the East. Hellenistic Relief Lamps of Eastern Mediterranean Provenance in Dalmatia. In: Lipovac Vrkljan G, Ožanić Roguljić I, Ugarković M (eds) Roman and Late Antique Lamps: production and distribution, contacts on the Mediterranean. Proceedings of the Round-Table, Zagreb, Institute of Archaeology, 2nd of February 2015. Institute of Archaeology, Zagreb, pp 18-37

Waldner A (2016) Keramik. In: Rathmayr E (ed) Hanghaus 2 in Ephesos, Die Wohneinheit 7, Baubefund, Ausstattung, Funde, Forschungen in Ephesos 8.10. ÖAW, Vienna, pp 311-423

Waldner A, Ladstätter S (2014) Keramik. In: Thür H, Rathmayr E (eds) Hanghaus 2 in Ephesos. Die Wohneinheit 6, Baubefund, Ausstattung, Funde, Forschungen in Ephesos 8.9. ÖAW, Vienna, pp 435-588

Walters HB (1914) Catalogue of the Greek and Roman Lamps in the British Museum. British Museum Publications, London

Zabehlicky-Scheffenegger S, Sauer R, Schneider G (1996) Graue Platten aus Ephesos und vom Magdalensberg. In: Herfort-Koch M, Mandel U, Schädler U (eds), Hellenistische und kaiserzeitliche Keramik des östlichen Mittelmeergebietes. Kolloquium Frankfurt 24.-25. April 1995. Arbeitskreis Frankfurt und die Antike, Archäologisches Institut der Johann Wolfgang Goethe-Universität, Frankfurt am Main, pp. 41-59

Zhuravlev D, Zhuravleva N (2014) Late Hellenistic Pottery and Lamps from Pantikapaion: Recent Finds. In: Guldager Bilde P, Lawall ML (eds) Pottery, Peoples and Places. Study and Interpretation of Late Hellenistic Pottery, Black Sea Studies 16. Aarhus University Press, Aarhus, pp 255-286

Publisher's note Springer Nature remains neutral with regard to jurisdictional claims in published maps and institutional affiliations. 